NBER WORKING PAPER SERIES

\title{
THE IMPACT OF DIRECT-TO-CONSUMER ADVERTISING ON PHARMACEUTICAL PRICES AND DEMAND
}

\author{
Dhaval Dave \\ Henry Saffer \\ Working Paper 15969 \\ http://www.nber.org/papers/w15969
NATIONAL BUREAU OF ECONOMIC RESEARCH
1050 Massachusetts Avenue
Cambridge, MA 02138

May 2010

This research was supported by a grant from the Agency for Healthcare Research and Quality to the National Bureau of Economic Research. We would like to thank Gregory Colman and seminar participants at the University of Connecticut for valuable comments. Li Ma and Zhen Ma provided excellent research assistance. The views expressed herein are those of the authors and do not necessarily reflect the views of the National Bureau of Economic Research.

NBER working papers are circulated for discussion and comment purposes. They have not been peerreviewed or been subject to the review by the NBER Board of Directors that accompanies official NBER publications.

(C) 2010 by Dhaval Dave and Henry Saffer. All rights reserved. Short sections of text, not to exceed two paragraphs, may be quoted without explicit permission provided that full credit, including $\odot$ notice, is given to the source. 
The Impact of Direct-to-Consumer Advertising on Pharmaceutical Prices and Demand Dhaval Dave and Henry Saffer

NBER Working Paper No. 15969

May 2010

JEL No. D21,I11,I18,K0,K2

\begin{abstract}
$\underline{\text { ABSTRACT }}$
Expenditures on prescription drugs are one of the fastest growing components of national health care spending, rising by almost three-fold between 1995 and 2007. Coinciding with this growth in prescription drug expenditures has been a rapid rise in direct-to-consumer advertising (DTCA), made feasible by the Food and Drug Administration's (FDA) clarification and relaxation of the rules governing broadcast advertising in 1997 and 1999. This study investigates the separate effects of broadcast and non-broadcast DTCA on price and demand, utilizing an extended time series of monthly records for all advertised and non-advertised drugs in four major therapeutic classes spanning 1994-2005, a period which enveloped the shifts in FDA guidelines and the large expansions in DTCA. Controlling for promotion aimed at physicians, results from fixed effects models suggest that broadcast DTCA positively impacts own-sales and price, with an estimated elasticity of 0.10 and 0.04 respectively. Relative to broadcast DTCA, non-broadcast DTCA has a smaller impact on sales (elasticity of 0.05) and price (elasticity of 0.02). Simulations suggest that the expansion in broadcast DTCA may be responsible for about 19 percent of the overall growth in prescription drug expenditures over the sample period, with over two-thirds of this impact being driven by an increase in demand as a result of the DTCA expansion and the remainder due to higher prices.
\end{abstract}

Dhaval Dave

Bentley University

Department of Economics

175 Forest Street, AAC 195

Waltham, MA 02452-4705

and NBER

ddave@bentley.edu

Henry Saffer

NBER

365 Fifth Avenue, 5th Floor

New York, NY 10016-4309

and NBER

hsaffer@gc.cuny.edu 


\section{Introduction}

Between 1995 and 2007, expenditures on prescription drugs increased by 274 percent, raising its share of total health care spending from six percent to over ten percent and making it one of the fastest growing components of health care costs. ${ }^{1}$ The growth in prescription drug expenditures has coincided with the growth in pharmaceutical promotion which increased from $\$ 11.4$ billion in 1996 to $\$ 29.9$ billion in 2005 (Donohue et al. 2007). Promotion of prescription drugs is generally limited to drugs under patent protection, and includes direct-to-consumer advertising (DTCA) on broadcast media and in print media as well as direct-to-physician promotion (DTPP) through visits by company representatives to physician offices (known as detailing), free samples provided to physicians and advertising in professional journals.

The largest increase in promotion resulted from the expansion of DTCA into broadcast media. This expansion was precipitated by the Food and Drug Administration's (FDA) clarification of the rules governing broadcast advertising. These changes began in 1995 with a request for public comment, and culminated in August of 1999 with FDA directives eliminating the requirement that broadcast advertising include detailed information on indications, side effects and proper usage. The new regulations made it feasible for pharmaceutical companies to promote their products via television and radio advertisements. DTCA spending increased from $\$ 150$ million in 1993 to $\$ 4.24$ billion in 2005 .

These new regulations, which allow broadcast DTCA, remain a controversial policy. Currently, only the U.S. and New Zealand permit broadcast DTCA. DTCA is facing increased scrutiny from Congress and consumer groups. Congressional leaders have contended that DTCA raises prescription drug costs and requested that the policy be revisited. Legislation requiring moratoriums on advertising new prescription drugs has been proposed but defeated

\footnotetext{
${ }^{1}$ See Centers for Medicare and Medicaid Services: http://www.cms.hhs.gov/NationalHealthExpendData/02 NationalHealthAccountsHistorical.asp
} 
as a violation of the protection of commercial speech. ${ }^{2}$ Some consumer groups maintain that the recent increases in DTCA are responsible for the increases in expenditures on prescription drugs. Families USA (July 2003) claimed that prescription drug advertising has been disproportionately focused on newer, higher-priced products and linked to an increase in the use of those products. Similarly, the National Institute for Health Care Management (November 2001) claimed that increases in sales for the 50 most heavily advertised drugs caused 47.8 percent of the increase in expenditures on prescription drugs.

Growth in prescription drug spending is broadly driven by increases in utilization, increases in price, and shifts in the composition of drugs being used, all of which may be impacted by DTCA. DTCA can raise the demand for existing drugs and also affect their price elasticity. The increase in demand can be beneficial if it improves adherence (Bradford et al., 2006; Donohue et al., 2004) or makes individuals aware of the existence of drug therapies for their health conditions. Expenditures have also increased, in part, due to the fact that newer drugs generally cost more than older drugs, and DTCA might induce substitution to these newer, more expensive drugs which also tend to be more heavily advertised. This may be health-promoting since newer drugs have been shown to be more effective in improving health than older drugs (Lichtenberg and Virabhak, 2002). Treatment through prescription drugs can also be more cost-effective than alternative and more intensive therapies, inducing some substitution among these forms of care. ${ }^{3}$ Recent estimates by Lichtenberg (2007) indicate that an extra dollar of spending on newly introduced drugs reduces non-drug medical spending by almost $\$ 7$, most of which is due to a reduction in inpatient hospital costs.

A key component of this question of the extent to which the growth in DTCA has contributed to rising prescription drug costs relates to how DTCA affects drug prices. To the

\footnotetext{
${ }^{2}$ Original provisions in the bill requiring mandatory moratoriums on the advertising of newly approved prescription drugs were removed when the Food and Drug Administration and Revitalization Act was signed into law in 2007.

${ }^{3}$ For instance, the compound cimetidine, discovered in the 1970 s and sold under the brand-name Tagamet, was the first effective anti-ulcer drug and had a revolutionary impact on treatment. It profoundly decreases acid secretion and precludes the need for surgery.
} 
best of our knowledge, no prior studies have investigated the impact of DTCA on prescription drug prices. This study adds to the literature with an empirical investigation of the role of prescription drug promotion on the price of prescription drugs. Prior studies, which have explored the effects of consumer advertising on sales, have also not differentiated between broadcast and non-broadcast DTCA and have arrived at mixed conclusions regarding the impact of total DTCA on own-sales. This study also adds to this literature by separately considering the effects of broadcast and non-broadcast DTCA, which is important for two reasons. First, the natural experiment afforded by the shift in FDA guidelines specifically applies only to broadcast DTCA; the composition of DTCA has shifted away from print and towards television and radio advertising as broadcast DTCA became more feasible as a form of promotion for the pharmaceutical industry. Second, both of these forms of DTCA may be expected to have differential effects on pharmaceutical prices and sales. Finally, this study also examines potential changes in the price elasticity of prescription drugs over the period during which DTCA was growing, which in turn may affect prices and demand.

\section{Background}

\section{Historical Background of DTCA}

The 1962 Kefauver-Harris Amendments to the Federal Food, Drug and Cosmetic Act shifted jurisdiction on regulating drug promotion from the Federal Trade Commission to the FDA and outlined the basic requirements for acceptable prescription drug marketing. Prescription drug promotional materials cannot be false or misleading, must provide "fair balance" coverage of risks and benefits of using the drug, must provide a "brief summary" of contraindications, side effects, and effectiveness, and must also meet specific guidelines for readability and size of

print. For a number of years, the FDA interpreted the "brief summary" provision as requiring the advertiser to provide the detailed information contained in the drug's FDA-approved product 
labeling, thereby confining it to print form, typically in small print. ${ }^{4}$ Expansion in broadcast DTCA was precipitated by the FDA's clarification of its regulation of consumer-directed advertising, particularly for broadcast advertisements. After a test period and request for public comment starting in 1995, the FDA approved the broadcast DTCA draft guidance in August 1997. It eliminated the requirement that ads present the entire "brief summary" taken from the product label insert. In August of 1999, the FDA further clarified the risk information requirements. Advertisements needed only to include "major statements" of the risks and benefits of the drug, along with directions to information sources in addition to a physician, such as a toll-free phone number, a website, or a print advertisement. This clarification of the requirements for adequate disclosure removed a major barrier that had initially made television and radio advertising infeasible and had initially relegated advertising directed at consumers to print media only.

Figure 1 shows annual DTCA spending for all prescription drugs from 1993 through 2005. Even from the annual aggregated data it is apparent that the growth in DTCA accelerated in 1996 as the FDA was "testing" the new guidelines and not enforcing the older standards for risk information disclosure, and again in 1999 and in 2000 following the official directive. Between 1996 and 2000, DTCA was the fastest growing component of pharmaceutical promotion, growing at an average annual rate of 33\%. In comparison, detailing and sampling grew at annual rates of $12-13 \%$, whereas professional journal advertising remained virtually unchanged. While the ratio of promotion to sales for the pharmaceutical industry has remained relatively stable at around 14 to $16 \%$, the share of DTCA in total pharmaceutical promotion has doubled to over $14 \%(2005)$ in just ten years (Figure 2). Figures 3 and 4 document DTCA spending, separated by broadcast and non-broadcast advertisements, for the four therapeutic classes examined in this study (described in the next section). Broadcast DTCA did not exist in

\footnotetext{
${ }^{4}$ There were two conditions under which firms could bypass the "brief summary" provision: 1) if the advertising were "help-seeking" and mentioned only disease symptoms and did not mention any drug name, or 2) if the advertisement is a "reminder" and mentions the drug name or its dosage without specifying what the drug is intended to treat.
} 
the sample prior to 1995; it commenced in 1995, coinciding with the FDA's intent to revisit its guidelines governing DTCA and institute a "test" period for public comment, and quickly overtook non-broadcast DTCA by 1998. The growth in broadcast DTCA again accelerated slightly in 1998, following the FDA's approval of the broadcast DTCA draft guidance in August 1997, and accelerated significantly in 2000 , following the FDA's clarification of the risk information requirements for broadcast DTCA in August 1999. While the FDA's shift in guidelines specifically applied to broadcast advertising, there is also an increase in nonbroadcast advertising starting in 2000 . This may be indirectly related to the FDA's clarification of the risk disclosure requirements. As the new guidelines required only "major statements" of the risks and benefits of the drug along with directions to alternate information sources for more complete information, there may have been a complementary increase in print advertisements. The feasibility of using television and radio advertisements may have raised the marginal product of other non-broadcast forms. Indeed, broadcast ads often direct consumers to concurrent ads in magazines or newspapers for more complete information on the drug's indications and contraindications.

The similar time-series pattern between total DTCA (across all drugs in the four therapeutic classes) in Figure 3 and mean DTCA (per advertised drug in the four therapeutic classes) in Figure 4 suggests that the large increase in total DTCA in the mid- to late-1990s was not driven by a shift in the number of prescription drugs or an influx of new entrants into the therapeutic classes. Figure 5 further bypasses the confounding effects of new entrants into the market by explicitly restricting the sample to a panel of drugs which existed in all periods from 1997 through 2002, showing similarly timed increases in DTCA. Figure 7 confirms that the number of available prescription drugs in the four therapeutic classes was roughly stable and not correlated with the spikes in DTCA spending

\section{Overview of Literature}


Many prior studies focus on how DTCA has affected pharmaceutical sales and patient adherence. Rosenthal et al. (2003) study brands in five therapeutic classes using aggregated U.S. monthly time series data from August 1996 through December 1999. They conclude that DTCA was primarily effective in raising sales for the entire therapeutic class, and attribute between 13 to 22 percent of the recent growth in drug spending to DTCA. Consistent with this market expansion effect of DTCA, lizuka and Jin (2005) find that a \$28 increase in DTCA leads to one additional drug visit within 12 months, based on DTCA data from 1994 through 2000 merged with the National Ambulatory Care Surveys. They also find that the market-expanding effect is similar across demographic groups. Ling, Berndt and Kyle (2002) examine the impact and inter-relationship of DTCA on sales of prescription and over-the-counter (OTC) anti-ulcer and heart-burn drugs based on monthly records from January 1988 through June 1999. They find some negative own effects, which depend on order-of-entry, and interestingly find positive spillover effects of promotion for prescription drugs on same-brand OTC versions of the drugs. Kalyanaram $(2009,2008)$ studies 14 advertised drugs from three therapeutic classes, comprising recent anti-depressants, proton pump inhibitors, and antihistamine drugs, based on monthly records from January 1998 through December 1999. While he does not consider cross-advertising effects, both studies find that within the sample of advertised drugs higher DTCA of a given prescription drug raises its market share (elasticities between 0.12 and 0.21 ), consistent with brand switching. The effects of physician-directed promotion are generally found to be larger than those for consumer-directed promotion. lizuka and Jin (2007) similarly find that promotional activities directed toward physicians have larger and longer lasting effects on brand choice than DTCA, suggesting that DTCA is more effective in increasing the aggregate demand per therapeutic class than in increasing the demand for a particular brand.

Kravitz et al. (2005) examine how DTCA impacts the prescribing behavior of antidepressants in a randomized control trial setting. Standardized patients, mostly professional actors, were randomly assigned to make 298 unannounced visits to family physicians and 
general internists. The patients made a specific brand request (referring to a DTC advertisement), a general drug request, or no request. Physicians prescribed antidepressants for the patients portraying general depression in $54 \%$ of the visits, including $76 \%$ of visits where the patients made a general request for a drug, $53 \%$ of visits where a specific drug was mentioned, and $31 \%$ where no drug was mentioned by the patient. Patients were prescribed Paxil in $27 \%$ of the visits where they explicitly mentioned the drug, compared to $4 \%$ where there was no request for a drug and $2 \%$ where the patients made a general request for a drug. For patients portraying adjustment disorder, $37 \%$ of patients requesting Paxil received a prescription for the drug, compared to $10 \%$ of patients who made a general drug request and none for patients who did not request any drugs. This study points to the role of brand-specific DTCA in raising own-demand by leading to a prescription for that brand, as well as in raising overall demand for prescription drugs in the therapeutic class.

Additional evidence on the demand effects of DTCA is also provided by studies that examine patient adherence. For instance, Calfee, Winston and Stempski (2002) find that DTCA on television increases adherence among patients being treated for high cholesterol. Bradford et al. (2006), using patient-level data from 1998 through 2004 merged with DTCA information, similarly find that higher levels of DTC television advertising of statin treatment is significantly associated with improvements in the likelihood of attaining cholesterol management goals for at least some patients. Donohue et al. (2004) study claims data for depressed patient between 1997 through 2000 matched with information on DTCA. They find that consumer advertising of anti-depressants is associated with an increase in the number of people diagnosed with depression who initiate medication therapy. DTCA is also associated with a small increase in the number of individuals treated with anti-depressants who received the appropriate duration of therapy. Most of these studies indicate positive demand effects of DTCA, and generally find that most of the increase in demand is focused on class-level effects whereas the effect of ownDTCA on the specific prescription drug is mixed. 
Studies have also examined the impact of advertising aimed at health-care providers, which historically has been the primary form of promotion used by the pharmaceutical industry. Berndt et al. (1995), for instance, consider the role of detailing, medical journal advertisements and DTCA in the market for anti-ulcer drugs prior to the shift in FDA guidelines. Thus, the DTCA examined in this study was very limited and confined only to print media. They find that the promotion stock increases demand for anti-ulcer drugs, with the strongest effect found for detailing and the smallest effect found for DTCA. This pattern of results, suggesting that detailing may be more effective in raising sales than DTCA, is also reported in Ling, Berndt and Kyle (2002) noted above.

Bhattacharya and Vogt (2003) present a model of price and promotion determination over the drug life cycle. In this model the pharmaceutical company faces a multi-period optimization decision and simultaneously manages price and promotion to influence consumer and physician knowledge about their drugs. Bhattacharya and Vogt (2003) show that the dynamic profit maximizing strategy for the firm is to initially employ a relatively high level of promotion and to set a relatively low price. These levels will not only increase current quantity demanded, but also raise future demand since high promotion and low prices increase the physicians' and the consumers' stock of knowledge about the drug. Since knowledge is costly to acquire, physicians' prescribing patterns can be sticky, and consumer use may also be sticky especially for chronic conditions, a high level of current demand translates into high demand in future periods. In subsequent periods, promotion can be decreased to lower costs and price can be raised to increase revenue. These rising prices represent the payoff from the firms' earlier investment in the drug's knowledge stock. After patent expiration, the earlier investment in knowledge stock can continue to push prices upwards. However, after patent expiration, if the drug remains on prescription, there is no longer a return to continued promotion (Frank and Salkever, 1992; Ling, Berndt and Kyle, 2002; Rosenthal, 2003). Bhattacharya and Vogt (2003) 
estimate a demand function and a price function based on a small sample of data, and the empirical results generally confirm the theory.

There is one study which directly addresses the effect of pharmaceutical promotion on price elasticity and thus indirectly addresses the effect on price. Rizzo (1999) studies the effect of detailing expenditures on the price elasticity of anti-hypertensive prescription drugs. He finds that increased detailing efforts reduce the price elasticity. This reduction may consequently result in higher prices, though Rizzo does not examine the direct link between detailing and price. The study is based on pooled annual data from 1988 to 1993, which predates the DTCA policy shift, and only considers direct promotion to physicians.

Since there have been no prior studies on the effect of DTCA on prescription drug prices, it is difficult to evaluate the extent to which DTCA has influenced the increase in prescription drug spending. It is also difficult to gauge how much, if any, of the growth in drug spending is due to an effect on sales versus an effect on price. In addition, most prior studies that have examined demand effects have aggregated both broadcast and non-broadcast DTCA, which may explain the mixed results. Such aggregation may not be appropriate since broadcast and non-broadcast DTCA could have differential effects on price and sales, which may be masked by the estimation of a single parameter of effect for aggregated DTCA. Most studies also employed DTCA information up to 2000 , and thus do not capture the periods of largest growth. This study contributes to these gaps in the literature, utilizing an extended time series of monthly records for all advertised and non-advertised prescription drugs in four major therapeutic classes spanning 1994 through 2005, a period which enveloped the shifts in FDA guidelines and the large expansion in DTCA.

This study also adds to the literature on the effects of physician-directed promotion within a fully specified model that controls for disaggregated broadcast and non-broadcast consumer advertising. Most of the prior demand studies have measured physician-directed promotion through detailing expenditures and/or promotion in medical journals. Medical journal 
advertising is not included in this study since it represents only about one percent of total promotional spending and has remained virtually unchanged over the past decade. The models estimated in this study consider alternate measures of physician promotion, including detailing, as measured by the total number of promotional physician contacts for each drug, the quantity of sampling for each drug as well as the value of this sampling based on the average wholesale price, thus yielding a more complete picture of the impact of physician-focused promotion on drug demand and prices.

\section{Analytical Framework}

The market for prescription drugs is differentiated from other markets both on the demand side and the supply side. On the demand side, physicians and insurance companies are involved in the consumption process. The physician provides a prescription for the drug, and is also a provider of information on the drug's indications and contraindications. The consumer can choose not to follow the physician's advice, but cannot legally consume without a prescription. Also, on the demand side, the insured consumer pays only a fixed copayment or fraction of the full retail price, with the pharmacies reimbursed for the cost by the insurance company. On the supply side, the pharmaceutical firm has a time-limited monopoly for the sale of its patented drugs. The firm can use promotion to physicians, promotion to consumers and pricing as tools for maximizing profits during the monopoly period and after patent expiration.

The theoretical basis of the demand function for prescription drugs involves constrained utility maximization by the consumer and profit maximization by the insurance and pharmaceutical companies. The consumer's demand for prescription drugs is derived from the consumer's underlying demand for health. Health is produced with medical inputs, including prescription drugs, physician advice and other factors (Grossman, 1999). The consumer has a derived demand for prescription drugs based on their underlying demand for health and other factors including the price and promotion of the drug. If the consumer paid the full retail price for the drug, then a conventional derived demand function would be defined. However, many 
prescription drug users are insured and pay only a fraction of the full retail price. Insurance coverage is therefore an important factor in the consumer's choice. Based on profit maximization, the insurance company must determine whether or not to provide coverage for the drug and the tier placement on the drug formulary ${ }^{5}$. This choice is affected by the negotiated price for the drug between the pharmacy benefit manager (a representative of the insurance companies) and the pharmaceutical firm, and on the demand for the drug by the clients of the insurance companies. At relatively higher prices fewer insurance companies will include coverage for the drug resulting in a downward sloping demand function. Promotion can increase underlying consumer demand for the drug, which in turn will increase demand for the drug by insurance companies. If a drug is not covered on the formulary, then increased promotion may result in a shift to coverage or a shift in the tier of coverage.

Drawing from this framework, the following demand function relates the quantity (sales) of a branded prescription drug to its price and various forms of promotion:

$$
\begin{aligned}
& \ln Q_{i m t}=\beta_{1}\left(\ln \text { Pr }_{\text {ice }}\right)+\beta_{2}\left(\text { BroadcastDTCA }_{i m t}\right)+\beta_{3}\left(\text { BroadcastDTCA }_{i m t}\right)^{2}+ \\
& \beta_{4}\left(\text { Non }- \text { BroadcastDTCA }_{i m t}\right)+\beta_{5}\left(\text { Non }- \text { BroadcastDTCA }_{i m t}\right)^{2}+ \\
& \beta_{6}\left(\operatorname{CrossDTCA}_{\text {imt }}\right)+\beta_{7}\left(\operatorname{CrossDTCA}_{\text {imt }}\right)^{2}+\beta_{8}\left(\operatorname{DTPP}_{\text {imt }}\right)+\beta_{9}\left(\operatorname{DTPP}_{\text {imt }}\right)^{2}+ \\
& \beta_{10}\left(\text { TimePatentExpiration }_{i m t}\right)+\beta_{11}\left(\text { TimePatentExpiration }_{i m t}\right)^{2}+\beta_{12}\left(\text { NumberDrugs }_{i m t}\right)+ \\
& \mu_{i}+\eta_{m}+v_{t}+\varepsilon_{i m t}
\end{aligned}
$$

Equation (1) denotes that sales $(Q)$ for the $i^{\text {th }}$ drug, in month $m$ of year $t$, are a function of its Price, Broadcast DTCA for the drug and Non-Broadcast DTCA for the drug. Sales for a given branded drug may also depend on advertising by other similar drugs in the market, captured here by Cross DTCA, which represents the total DTCA engaged in by all other drugs in the therapeutic class. Demand also depends on promotion geared towards physicians (denoted as direct-to-physician promotion DTPP). Diminishing returns are captured by including quadratic

\footnotetext{
${ }^{5}$ The drug formulary is a list of drugs for which a private or public insurer provides coverage. The formulary's pricing system is based on tiers of coverage that typically differentiate between generic drugs, preferred brand-name drugs, and other brand-name drugs. A drug's tier listing is a function of two factors: its real cost and the payer's negotiated cost. The more the drug costs the payer, the higher the tier, and the more it will cost patients.
} 
terms for all forms of promotion. Linear and quadratic effects of the time until patent expiration (TimePatentExpiration) account for the impact of the drug's life cycle on demand.

Competitiveness is captured by the number of prescription drugs in the therapeutic class (NumberDrugs), which changes over time as new drugs enter the market or if drugs are withdrawn from the market. Intercepts are suppressed for convenience, and $\varepsilon$ represents a classical disturbance term. ${ }^{6}$

A price function can be derived as a reduced form of the firm's output function and the demand function (equation 1). This results in the following reduced-form specification for price:

$$
\begin{aligned}
& \ln P_{i m t}=\alpha_{1}\left(\text { BroadcastDTCA }_{i m t}\right)+\alpha_{2}\left(\text { BroadcastDTCA }_{i m t}\right)^{2}+ \\
& \alpha_{3}\left(\text { Non }- \text { BroadcastDTCA }_{i m t}\right)+\alpha_{4}\left(\text { Non }- \text { BroadcastDTCA }_{i m t}\right)^{2}+ \\
& \alpha_{5}\left(\text { CrossDTCA }_{i m t}\right)+\alpha_{6}\left(\text { CrossDTCA }_{i m t}\right)^{2}+\alpha_{7}\left(\text { DTPP }_{i m t}\right)+\alpha_{8}\left(\text { DTPP }_{i m t}\right)^{2}+ \\
& \alpha_{9}\left(\text { TimePatentExpiration }_{i m t}\right)+\alpha_{10}\left(\text { TimePatentExpiration }_{i m t}\right)^{2}+\alpha_{11}\left(\text { NumberDrugs }_{i m t}\right)+ \\
& \mu_{i}+\eta_{m}+v_{t}+\omega_{i m t}
\end{aligned}
$$

Equation (2) denotes that the market price $(P)$ is a function of promotion, time until patent expiration and the number of drugs in the therapeutic class. Promotion may affect price through two different processes. First, promotion may increase demand and/or reduce the absolute magnitude of the demand-price elasticity, which may raise price. Second, the increase in operating costs due to higher promotional spending may be shifted to consumers in the form of higher prices. The coefficients in equation (2) capture the reduced-form effect of promotion on price and reflect both processes.

Equation (1) captures the direct effect of promotion on demand, conditional on price. However, since promotion may also indirectly affect demand through its effects on price, a reduced-form function for sales is also estimated.

\footnotetext{
${ }^{6}$ A double-log specification with respect to price and a semi-log specification with respect to promotional spending is employed for ease of interpretation (resulting effects are interpreted as relative changes in sales) and to allow for drugs that do not advertise at all or those that may not advertise in certain months. The general pattern of results and overall conclusions are not sensitive to a fully linear specification or a semi-log specification with respect to both price and promotion.
} 
$\ln Q_{\text {imt }}=\lambda_{1}\left(\right.$ BroadcastDTCA $\left._{\text {imt }}\right)+\lambda_{2}\left(\text { BroadcastDTCA }_{\text {imt }}\right)^{2}+$

$\lambda_{3}\left(\right.$ Non - BroadcastDTCA $\left._{\text {imt }}\right)+\lambda_{4}\left(\text { Non }- \text { BroadcastDTCA }_{\text {imt }}\right)^{2}+$

$$
\begin{aligned}
& \lambda_{5}\left(\operatorname{CrossDTCA}_{\text {imt }}\right)+\lambda_{6}\left(\operatorname{CrossDTCA}_{\text {imt }}\right)^{2}+\lambda_{7}\left(\text { DTPP }_{\text {imt }}\right)+\lambda_{8}\left(\text { DTPP }_{\text {imt }}\right)^{2}+ \\
& \lambda_{9}\left(\text { TimePatentExpiration }_{\text {imt }}\right)+\lambda_{10}\left(\text { TimePatentExpiration }_{\text {imt }}\right)^{2}+\lambda_{11}\left(\text { NumberDrugs }_{\text {imt }}\right)+ \\
& \mu_{i}+\eta_{m}+v_{t}+\psi_{\text {imt }}
\end{aligned}
$$

The coefficients in this function reflect the net effects of promotion (and other factors) on sales, capturing both the direct effects and any indirect effects through changes in drug prices.

\section{Empirical Concerns}

One potential concern with respect to identifying the impact of consumer-directed advertising relates to the reverse causality between DTCA and sales, and between DTCA and price. Such structural endogeneity is less of a concern for the sample studied for two reasons. First, the growth in DTCA in the late 1990s and early part of this decade, made possible by the FDA's change in guidelines governing broadcast advertising, is likely exogenous to the drug's sales and price. Thus, the sample period under study provides a natural experiment for the estimation of the impact of DTCA. To further exploit this natural experiment and minimize any potential reverse causality between sales or price and advertising, models are estimated for the period immediately enveloping the FDA's change in guidelines and the subsequent expansion in DTCA. Models are also estimated for a balanced sample of drugs that were on-patent over the time period under study in order to eliminate bias from the selection of new drugs into the market as a result of the FDA's shift in guidelines. Thus, prior to 1996, these drugs did not engage in any broadcast DTCA since it was not feasible under the old guidelines. They expanded into broadcast DTCA starting in the late 1990s as a result of the FDA's shift in the governing rules for DTCA. This increase in DTCA for the balanced panel is plausibly exogenous to sales and price and related directly to the shift in policy.

Another potential source of endogeneity stems from the unique situation of a time limited monopoly. In the multi-period optimization framework considered by Bhattacharya and Vogt 
(2003), the firm simultaneously manages price and promotion to determine sales and maximize profits over the drug's life cycle. The dynamic profit maximizing strategy for a pharmaceutical firm is to initially employ a relatively high level of promotion and set a relatively low price to increase current demand and future demand by raising consumers' and physicians' stock of knowledge regarding the drug. Over time, promotion would decline and prices would rise. ${ }^{7}$ This is not structural endogeneity but rather correlational or statistical endogeneity since changes in sales, price, and promotion are partly governed by the drug's life cycle. Such endogeneity bias is bypassed since all models control for time-to-patent expiration.

Another estimation concern is that certain drugs are more likely to be advertised to consumers. lizuka (2004) finds evidence that higher quality drugs (as measured by the FDA's priority rating) are more likely to engage in DTCA. lizuka also finds that potential market size (based on prevalence rates for selected chronic conditions) also increases DTCA. All models control for this selection effect by including drug-level fixed effects $\left(\mu_{\mathrm{i}}\right)$. This accounts for any time-invariant heterogeneity across drugs such as quality, fixed R\&D costs, contraindications and potential market size. The drug-level fixed effects also account for differences in dosage and units across drugs. Models are also estimated separately for drugs which are everadvertised and drugs which are never-advertised since advertised drugs as a group are likely to be different from non-advertised ones along unobserved characteristics. Unobserved seasonal factors and unobserved national trends (for instance, relating to prescription drug insurance, changes in population health, national regulations, or size of the affected market) are accounted for by a set of month $\left(\eta_{m}\right)$ and year $\left(v_{t}\right)$ fixed effects.

With drug and time fixed effects, identification comes from comparing changes in DTCA to changes in price and sales within each specific branded drug. While the drug and time fixed effects also account for systematic unobserved factors that may lead to autocorrelated errors and non-uniform variances across drugs, all models also further correct standard errors for

\footnotetext{
${ }^{7}$ In the dataset, there is evidence of this life-cycle trajectory (as shown in Figures 8-10).
} 
drug-specific heteroscedasticity and for first-order autocorrelation (with the autocorrelation coefficient allowed to differ across drugs). All models control for drug fixed effects in order to account for unobservable intrinsic differences in the price elasticity across drugs that may in turn lead to variations in DTCA. In addition, shifts in the price elasticity for a particular drug over its life cycle are generally a function of new entrants and availability of substitutes. Thus, all models also control for the number of other prescription drugs in the therapeutic class as well as linear and quadratic effects of time to patent expiration.

\section{Data}

Analyses are based on prescription drugs in four major therapeutic classes: 1) analgesics/musculoskeletal, 2) anti-lipidemics, 3) gastrointestinal acid reducers, and 4) insomnia aids. The prescription drugs in these four therapeutic classes had combined sales of $\$ 48.9$ billion in 2005 , representing 24 percent of total prescription drug spending for the U.S. DTCA in these therapeutic classes amounted to $\$ 1.04$ billion in 2005 , approximately 25 percent of total DTCA undertaken for all prescription drugs. These therapeutic classes were chosen since they include one or more drugs with relatively high levels of DTCA spending and other drugs with little or no DTCA. The drugs in these therapeutic classes also treat a wide variety of highly prevalent ailments and are indicated for large segments of the population. Over 45 percent of Americans ages 20 years and older have borderline-high or high cholesterol levels (Lloyd-Jones et al., 2009). Estimates of the use of cholesterol reducing drugs range from 11 million to 30 million users. ${ }^{8}$ According to the National Health Interview Surveys (2003-2005), 46 million adults (22\%) have reported having a diagnosis of arthritis. One report finds that 89 percent of individuals with arthritis have used prescription medications. ${ }^{9}$ Similarly, insomnia afflicts about 30 percent of adults in the United States (Roth, 2007). While the majority of these individuals does not use any medications or alternately relies on over-the-counter treatments,

\footnotetext{
${ }^{8}$ http://www.forbes.com/2008/10/29/cholesterol-pharmacuticals-statins-biz-cx mh 1030cholesterol.html 9 http://ihcrp.georgetown.edu/agingsociety/pdfs/rxdrugs.pdf
} 
the use of prescription sleep aids has been increasing over the past decade. ${ }^{10} \mathrm{~A}$ populationbased study found that about 59 percent of the population has heartburn or acid regurgitation at least once during the course of a year and that 20 percent experience symptoms at least once weekly (Locke et al., 1997).

The data set is a monthly time-series, spanning 1994 to 2005 , of all advertised and nonadvertised prescription drugs in these four therapeutic classes. This sample period envelopes the natural experiment that expanded the use of pharmaceutical DTCA. Basing the analyses on both advertised and non-advertised drugs bypasses sample selection issues, results in a more representative sample of the overall market, and lends some external validity to the findings.

A listing of all prescription drugs within each of the four therapeutic classes was obtained from the Physicians' Desk Reference (various years). For each prescription drug-year-month cell, information on DTCA and DTPP, sales, price, and patent expiration were obtained from three sources. Competitive Media Reporting (CMR) collects DCTA for all major media, and is widely recognized in the industry as the primary source of advertising information. Data reported by CMR are independent estimates and are not based on any information from pharmaceutical companies. For this study, DTCA is categorized separately into broadcast (network, local spot, and cable television; network and local spot radio) advertising and nonbroadcast (magazines, newspapers, outdoors, and internet) advertising.

The measure of advertising is constructed to include the current month's advertising and a decay-weighted sum of past advertising. According to prior studies in the advertising literature, the impact of advertising can linger beyond the time of its presentation. While there is no specific guidance on the decay rate, studies of consumer goods generally find that the effects of past advertising are fully depreciated within one year. The lingering effect of

\footnotetext{
${ }^{10}$ For instance, there was a 50 percent increase in the use of prescription sleep aids by adults between the ages of 18 and 45. Prevalence for the use of prescription sleep aids has been estimated at 1524, 2528, and 4399 (per 100,000 population) for the $18-24,25-34$, and $35-44$ age ranges, respectively. See http://www.thomsonreuters.com/content/healthcare/pdf/394449/Thomson Reuters Research Br1.pdf
} 
advertising in the prescription drug market may be more prolonged than in consumer goods markets due to the time lags between advertising exposure, scheduling a physician visit, and obtaining and filling the required prescription. A decay rate of 0.1 was used to construct the advertising variable. With a decay rate of $0.1,72$ percent of the impact of advertising has depreciated by the $12^{\text {th }}$ month. The advertising stock for month $t$ is defined as:

$\sum_{i=0 \text { to } 11}\left(D_{T C A} A_{t-i}\right)(1-d)^{i}$, where t-i=0 represents the contemporaneous month's broadcast or nonbroadcast DTCA and $d$ represents the decay rate. ${ }^{11}$

Information on DTPP, drug sales, and drug price are obtained from IMS Health. Three measures of DTPP are utilized in alternative specifications. Detailing is measured by the total number of promotional contacts with physicians relating to the specific drug, where a contact represents a product-level report of promotional actions. It is based on a panel of approximately 12,000 office- and hospital-based physicians, comprising roughly two percent of the U.S. physician population. DTPP also consists of the product sampling activities of pharmaceutical representatives. Sampling is measured in extended units, which have relevance only in relation to the specific drug in question. Thus, for instance, if the drug in question is Lipitor $40 \mathrm{mg}$, then this measure of sampling captures the total tablets or capsules of this form of Lipitor that were sampled in a given month and year. ${ }^{12}$ In addition, alternate models account for sampling expenditures, where sampling is valued at a manufacturer's list price known as the average wholesale price. ${ }^{13}$ Sales for each drug are measured as the total number of extended units sold each month. ${ }^{14}$ Monthly expenditures in dollars are also observed for each drug.

\footnotetext{
${ }^{11}$ Results and conclusions are not materially affected with alternate measures of the advertising stock based on decay rates of $0.2,0.3$ and 0.4 respectively.

${ }_{12}$ With drug-specific fixed effects, there are no comparisons of levels across any drug forms. Only within-drug identification is exploited, which makes it feasible to measure sampling with respect to the specific extended units of that drug.

${ }^{13}$ As expected, there is a high degree of correlation between detailing and sampling $(0.88)$ and between detailing and the retail value of sampling $(0.83)$.

${ }^{14}$ Similar to the measure of sampling, cross-drug variation in units, dosage, and administration are captured by the drug-specific fixed effects.
} 
Drug prices are measured by the average retail price. This is the average price of a tablet, capsule, milliliter, or other unit in the specified time period paid by a retail pharmacy. ${ }^{15}$ Insured individuals pay only a nominal prescription fee, and pharmacies are reimbursed by the insurance company for the residual. IMS Health provides a comprehensive overview of all prescription drugs dispensed by retail pharmacies in the U.S. Each month, information on over 140 million prescriptions is collected, projected, and summed to the national level for more than 35,000 U.S. retail pharmacies, including chains, independents, mass merchandisers, and food stores. Data are collected electronically and cover nearly 70 percent of all dispensed prescriptions.

Table 1 presents definitions and means for key variables, pooled across all drugs and classes, stratified by their DTCA status. Table 2 presents these summary statistics separately for the four therapeutic classes. Among drugs which have ever been advertised to consumers between 1994 and 2005, the average monthly advertising is \$1.61 million, 59 percent of which is broadcast DTCA with the remainder expended in non-broadcast media. Total expenditures on advertised drugs are significantly higher relative to non-advertised drugs. Since there is no significant difference in price at the aggregate level, the difference in expenditures is driven by substantially higher sales. ${ }^{16}$ Drugs with DTCA also utilize significantly more detailing and sampling than non-advertised drugs. For advertised drugs, sampling expenditures comprise about eight percent of sales, whereas for non-advertised drugs the sampling-to-sales ratio is less than four percent. ${ }^{17}$ Advertised drugs also tend to be newer, as measured by time to patent expiration; the average advertised drug has 7.3 years left before it loses patent protection. The

\footnotetext{
${ }^{15}$ An alternate measure of the average purchase price, based on the most popular dose as defined by total expenditures, is also employed in alternate specifications to check for robustness. Both measures are highly correlated (correlation coefficient $=0.99$ ).

${ }^{16}$ The lack of a significant difference in price between advertised and non-advertised drugs is due to the high level of aggregation across all drug classes. Mean price is also somewhat misleading due to skewness in the price distribution. Table 2 presents summary statistics disaggregated across the separate therapeutic classes.

17 These ratios are slightly overstated since IMS constructs the value of sampling based on the average wholesale price, which is usually higher than the average purchase price paid by a retail pharmacy. However, the general conclusion that DTPP is also higher for consumer-advertised drugs relative to non-advertised drugs is not affected.
} 
total number of drugs in the therapeutic class that are on the market is significantly lower for advertised drugs relative to non-advertised drugs. However, this difference is driven by variation in the prevalence of advertised versus non-advertised drugs across therapeutic classes. The data show that 69 percent of cholesterol-lowering drugs have been advertised to consumers. In comparison, about 50 percent of the insomnia drugs have been advertised, 39 percent of gastrointestinal drugs have been advertised, and only about 23 percent of antiarthritic drugs have been advertised over the sample period.

The data for the individual therapeutic classes are generally consistent with the overall data. Table 2 shows that on average, among advertised drugs, mean monthly DTCA is highest for sleep-aids (\$1.8 million) and lowest for anti-arthritic drugs (\$1.4 million). In contrast DTPP, both in terms of detailing as well as sampling, is highest for advertised anti-lipidemics and lowest for advertised sleep-aids. As confirmed in the aggregate means reported in Table 1, for all therapeutic classes, DTPP tends to be significantly higher for advertised drugs relative to drugs which are never advertised. Thus, it appears that DTCA and DTPP are complementary inputs. ${ }^{18}$ Advertised drugs also tend to be newer for all therapeutic classes. Among sleep-aids, all non-advertised drugs are on average off-patent, and advertised drugs are among the newest entrants to the market across all therapeutic classes. Disaggregating across therapeutic classes also draws forth significant differences in price between advertised and non-advertised drugs, which were previously confounded in the aggregated sample. Across all drug classes, the price of advertised drugs is significantly higher relative to the price of non-advertised drugs.

The unit of analysis is at the level of the specific drug form, that is any variation that arises within a drug due to dosage or administration. For instance, Ambien (the original singlelayered version) and Ambien CR (the newer controlled-release double-layered version) are

\footnotetext{
${ }^{18}$ This suggests that there may be systematic unobservable differences between drugs that are advertised to consumers and those that are never advertised, for instance related to the potential market, indications and contraindications, research and development expenditures, perceived quality, and such. While the drug-specific fixed effects will capture these unobservables to the extent that they are time-invariant, models are also estimated separately for both samples of drugs to explore differential effects of price and other promotion.
} 
treated as separate drug forms. DTCA information is matched specifically to the drug form advertised, when possible. For instance, advertising for Ambien CR is specifically matched to price and sales information for Ambien CR. In other instances, DTCA does not distinguish between alternate drug forms, and therefore it is matched to all forms of that drug. For instance, while Lipitor $10 \mathrm{mg}$ and $20 \mathrm{mg}$ are treated as separate observations with their own form-specific price, sales, and DTPP, the DTCA does not distinguish between these forms. Therefore, DTCA for Lipitor is matched to all forms of Lipitor. ${ }^{19}$ Fixed effects, at the level of the specific drug form, control for all unobserved time-invariant differences across drugs, relating to efficacy, indications and contraindications, administration, and specific initial research and development costs for the drug in question. Since the drugs in the sample are nested within each pharmaceutical firm, the drug-level fixed effects also account for unobservable differences across firms including a company's general propensity to advertise or promote its drugs. This yields a final estimation sample size of 14,157 drug-year-month observations.

\section{Results}

Table 3 presents results for the demand specification noted in equation (1), based on total DTCA stock, and compares drugs that are marketed to consumers and physicians with drugs that are only marketed to physicians. Since patent expiration and generic entry may simultaneously affect sales, pricing and promotion, the sample is restricted to include only onpatent drugs and time periods. ${ }^{20}$ Alternative specifications control for the different forms of DTPP. Price has a negative and significant effect on sales; the price elasticity is slightly lower for advertised drugs (-0.67) relative to non-advertised drugs $(-0.73)$ across all specifications, though the difference is not statistically significant. For the sample of advertised drugs, the stock of own broadcast DTCA has a significant positive impact on sales conditional on price,

\footnotetext{
${ }^{19}$ For cases where the DTCA did distinguish between drug forms (for instance, Ambien), an alternate matching based on aggregated DTCA for all forms of the same drug yielded very similar results.

${ }^{20}$ Most non-advertised drugs are off-patent. Hence, restricting the sample to drugs and periods on patent allows a more consistent comparison between advertised and non-advertised drugs.
} 
with the elasticity (evaluated at the sample means) ranging from 0.13 to 0.19 . The stock of DTCA engaged by other drugs in the therapeutic class (Cross DTCA), on the other hand, appears to have a negative impact on the sales of the specific advertised drug (elasticity of 0.09 to -0.13$)$. In contrast, cross-DTCA tends to raise sales for non-advertised drugs. This is consistent with prior studies, which have found that DTCA can expand the total market for drugs within a therapeutic class. These studies generally did not differentiate between advertised and non-advertised drugs. In differentiating these two groups, the results indicate that total crossDTCA may specifically benefit the market for cheaper, substitutable non-advertised drugs. That is, while an individual may be induced by DTCA to visit a physician, some physicians may prescribe a different drug that may be non-advertised and lower cost. Weissman, Blumenthal, Silk et al. (2004) survey a national sample of 632 physicians. Among the $61 \%$ of DTCA visits that did not result in a prescription for the advertised drug, the physician prescribed a less costly equally-effective drug in about 25 percent of the cases.

Among advertised drugs, DTPP has a significant positive effect on sales, and the salesdetailing $(0.51)$ or sales-sampling elasticity $(0.34)$ is substantially larger relative to the sales-own DTCA elasticity $(0.13$ to 0.19$)$. This is consistent with the literature, which also generally concludes that detailing is more effective at raising own-sales than DTCA (Kalyanaram, 2009; lizuka and Jin, 2007). The effectiveness of physician-directed promotion in raising sales is also higher for advertised drugs relative to non-advertised drugs. This suggests that DTCA and DTPP may be complementary, with DTCA enhancing the productivity of DTPP.

Table 4 presents estimates for the reduced-form sales function (equation 3 ) for the sample of drugs which are ever-advertised to consumers, separating the effects of broadcast and non-broadcast DTCA. ${ }^{21}$ Specifications 1 and 2 utilize the full sample of advertised drugs

\footnotetext{
${ }^{21}$ Drugs which are never advertised to consumers differ along observable factors (DTPP, time to patent expiration, price, sales) and are also likely to differ along unobservable characteristics. They continue not to engage in DTCA even after the FDA's shift in guidelines. Therefore, limiting the focus to drugs which advertise at some point to consumers results in a more homogeneous sample; the shift in DTCA is also likely to be more exogenous for this sample, being driven by the FDA's clarification of promotional guidelines.
} 
across all periods, and control for alternative measures of DTPP. Both broadcast and nonbroadcast DTCA positively impact sales on average, and there is suggestive evidence that the impact of broadcast DTCA in raising sales is relatively larger. Specification 2 controls for both detailing and sampling, with the respective elasticities estimated at 0.35 and 0.09 . Crossadvertising effects are generally insignificant. Conditional on price, promotion and other factors, the coefficients on the time-to-patent expiration terms indicate a generally increasing sales trajectory over the life cycle at least up to some point. Specification 3 limits the analysis for periods up to 2002; as shown in Figures 3-5, the largest increase in DTCA occurred between 1999 and 2000 as a result of the FDA's clarification of the risk information requirements in August 1999. With up to a one-year lag in impact, such an increase in DTCA would be expected have an effect up to 2001. Probing beyond 2002 gets further away from the natural experiment and the plausibly exogenous increase in DTCA, and further poses the risk of introducing confounding trends. For this restricted sample, the results remain unchanged, and if anything, the impact of broadcast DTCA becomes larger in magnitude (elasticity of 0.11 ).

Specification 3 further restricts the study sample to 1997 through 2002, peering over a three-year pre- and post-window surrounding the largest discontinuous increase in DTCA occurring over 1999-2000. It also envelopes the increase in DTCA that occurred over 19971998, subsequent to the FDA's approval of the broadcast DTCA draft guidance in August 1997. Specification 4 utilizes this same sample period but further restricts the analysis to on-patent drugs and time periods in order to bypass any confounding from the generic entrants. The price elasticity for broadcast DTCA is estimated at around 0.11 and that for non-broadcast DTCA ranges from 0.03 to 0.07 .

Earlier specifications had shown that total own-DTCA raises sales. The results from Table 4 suggest that most of this effect is being driven by broadcast DTCA. The disparity in the effectiveness of broadcast versus non-broadcast DTCA may be related to differences in their content. Television and radio advertising messages often provide a brief description of the side 
effects and mainly focus on what the drug is intended to treat; broadcast DTCA often directs the consumer to print advertising for more detailed information on the drug including the "fine print" on indications and contraindications.

The final specification in Table 4 limits the sample to a balanced panel of drugs that remain under patent from 1997 through 2002. This specification bypasses any confounding from new drug entrants, which generally engage in relatively large promotional spending and may cost more than the older drugs. Thus, any increase in DTCA for this sample is plausibly due to the FDA's policy shift. For instance, the sleep-aid Ambien has been on the market since late-1992. It did not engage in broadcast DTCA in 1997,1998 or 1999 . In 2000 , following the FDA's clarification of the risk information that made broadcast DTCA feasible, Ambien started being advertised on television for the first time since it had entered the market; average monthly broadcast DTCA amounted to $\$ 310,000$ in this year. In 2001 , average monthly broadcast DTCA increased to $\$ 1.81$ million. Similarly, Lipitor entered the market in late 1996; it engaged in $\$ 31,000$ of average monthly broadcast advertising in 1998 after the FDA issued its initial draft guidance concerning DTCA. This increased to \$2.65 million in 1999 and \$3.51 million in 2000 . Thus, specification 6 is exploiting this variation, subsequent to the FDA's policy shifts, to investigate whether such increases in broadcast DTCA led to higher drug prices. The estimates remain robust and continue to suggest that broadcast DTCA raises prescription drug sales, with an elasticity that is higher than that for non-broadcast DTCA (0.09 vs. 0.03$)$. Sampling also appears to raise sales with an estimated elasticity $(0.06)$ that falls in between those for broadcast and non-broadcast DTCA.

Combining the reduced-form elasticities for broadcast and non-broadcast forms, the total DTCA elasticity is slightly lower relative to those reported in Table 3 (specifications which control for price). This suggests that DTCA may have a small positive impact on price, which in turn is reducing sales; thus, the reduced-form net effect of DTCA on sales is somewhat lower than the effect that holds price constant. Table 5, which presents the estimates of the reduced- 
form price function (equation 2), confirms this. Broadcast DTCA appears to raise prescription drug prices, with an estimated elasticity ranging from 0.02 to 0.05 . The estimated elasticity is generally larger in magnitude as the sample and time periods are narrowed around the shift in rules governing broadcast DTCA. There is some suggestive evidence that non-broadcast DTCA may also raise prices, though the elasticity magnitude is relatively smaller $(0.02)$. There is no evidence that cross-DTCA or DTPP have any significant effects on prescription drug prices. The final two specifications, which limit the analysis to on-patent drugs from 1997-2002, indicate a generally declining price trajectory over the life cycle, conditional on promotion and other factors.

The impact of DTCA on sales and price may partly be a result of a shift in the price elasticity as DTCA became more prevalent. Table 6 explores this possibility by estimating the demand function denoted in equation (1), stratifying the sample period into the three years (1997-1999) prior to the largest increase in DTCA and the three years (2000-2002) subsequent to this increase. Average monthly DTCA increased by 239 percent over these two periods. Comparing the price elasticity estimates in specifications 1 and 2, it appears that consumers have become less responsive to drug prices in the latter period, concurrent with the large increase in DTCA. The same conclusion emerges from specification 3, which restricts the sample to a balanced panel of drugs, thus bypassing issues of sample selection from new drug entrants into the market. Thus, even for the same drugs that existed on the market over these six years, price elasticity appears to have declined. This decline in the price elasticity cannot be explained by general expansions in health insurance or prescription drug insurance (which would be captured by the time fixed effects). It also cannot be explained by time-varying factors that are specific to the therapeutic drug class, for instance increases in the prevalence of obesity or underlying illness conditions that the drugs are supposed to treat, changes in the regulatory framework separately affecting each drug class such as lags to FDA approval, or overall shifts in R\&D expenditures specific to a drug class. Specification 4 controls for drug 
class-specific year fixed effects, which account for all unobserved time-varying factors specific to each therapeutic class; the estimates are not significantly affected. The effects of promotion are imprecisely estimated in some cases due to the smaller sample size, though the main pattern of results from the earlier specifications remains robust. Broadcast DTCA appears to raise sales, and there is not a significant change in its average elasticity over the periods (ranging from 0.04 to 0.07 ), though it continues to be more effective in raising sales than nonbroadcast DTCA. The elasticity of sampling is estimated at 0.03 to 0.06 .

\section{Sensitivity Analysis}

Several additional analyses were implemented to assess the robustness of the previous findings. ${ }^{22}$ The previously reported results are based on the pooled sample of drugs from the four therapeutic classes. Stratifying analyses by drug class is not feasible due to limited sample sizes. Nevertheless, two alternative sets of models are estimated to ascertain that the results are not being driven by drugs in a particular therapeutic class. First, all models were reestimated with the inclusion of drug class-specific time fixed effects to account for unobserved time-varying class-specific factors. Second, models were re-estimated by excluding one drug class in turn, that is by pooling different sets of three therapeutic classes. The general pattern and magnitude of the estimates remain robust; in some cases standards errors do increase when sample sizes drop, though the general conclusions remain unaltered. This suggests that the effects of DTCA on demand and price are not sensitive to a particular class of drugs and raises confidence in the external validity of the findings.

The general pattern and magnitude of the estimates are also not sensitive to variations in the specification, for instance utilizing a linear functional form versus a semi- or double-log form with respect to some variables, controlling for life-cycle effects non-parametrically through dichotomous indicators for years to patent expiration versus parametrically through linear and quadratic terms, and controlling for alternate measures of the crowdedness of a therapeutic

\footnotetext{
${ }^{22}$ Results from these alternate specifications are available upon request.
} 
class (for instance, total number of other prescription drugs in the therapeutic class, total number of other consumer-promoted drugs in the therapeutic class, total number of other broadcast-promoted drugs in the therapeutic class).

\section{Conclusions}

DTCA should be evaluated both in terms of its benefits and its costs. The benefits derive from improved health due to increases in the number of individuals using prescription drugs and increased adherence with drug therapy. Detecting and treating health conditions at an earlier stage, through primary care, may also be more cost-effective relative to treatment at a later stage through acute care. The costs of DTCA result from increased drug prices and increased use of more expensive drugs in place of equally effective lower-priced drugs. Higher

drug and health care expenditures in general tend to raise insurance premiums and may lead to a larger prevalence of uninsured. This study focuses on the cost-side and provides the first empirical estimates of the impact of the expansions in DTCA on prescription drug prices. It also contributes to the literature by differentiating the effects of broadcast and non-broadcast DTCA.

A consistent pattern of results emerges with respect to the following. DTCA is found to positively impact own-sales of the advertised drugs, with most of this effect being driven by broadcast DTCA (elasticity of about 0.11 for broadcast DTCA versus 0.03 to 0.05 for nonbroadcast DTCA). Prior studies, which at times found conflicting evidence on the impact of own-DTCA on own-sales, may have been confounded by aggregating broadcast and nonbroadcast forms. In periods predating the FDA's shift in guidelines, virtually all of DTCA was relegated to non-broadcast media, whereas starting in 1998 advertising in broadcast media overtook non-broadcast advertising and became the primary form of DTCA. Therefore, the effect of total DTCA, being a weighted average of the effect of the two separate forms, would be 
expected to vary depending on the time period under study and the relative composition of total DTCA between non-broadcast and broadcast media. ${ }^{23}$

Both forms of physician promotion considered in this study, detailing and sampling, also raise sales, with the largest elasticity estimated for detailing. The elasticity estimates of detailing from some of the prior studies may have been confounded by the correlation between detailing and the DTCA stock and between detailing and sampling, which is the primary form of DTPP. Some prior studies have shown that DTCA may raise total sales in the drug class. By disaggregating advertised drugs from never-advertised drugs, the results indicate that specifically class-level cross-DTCA may have a small negative or zero effect on the sales for the advertised drugs but raises sales for the non-advertised, cheaper drugs. There is also consistent evidence that DTCA, specifically broadcast DTCA, has positively impacted drug prices, though the estimated elasticity is relatively small (0.05). Part of the positive relationship between DTCA and drug prices may be related to the shift in demand.

The relative price insensitivity of prescription drugs (elasticity of about -0.67 to -0.73 ) may be the result of physicians and insurance companies which mediate the consumption process. Physicians' prescribing behavior is insensitive to price, reflects their general risk aversion and resistance to change. Consumers are also insensitive to costs due to the reimbursement procedures. Thus, the impact of DTCA on drug demand, prices and the price elasticity reflects both the combined decision making and behaviors of consumers as well as health care providers.

\footnotetext{
${ }^{23}$ For instance Kalyanaram (2008) finds a small but significant impact of DTCA on product market share, whereas the estimated effects of DTCA on product market share are generally insignificant and inconsistent in Rosenthal et al. (2003). They conclude on "the impact of DTCA spending at the individual product level as still remaining quite uncertain..." While the differing results may partly be attributed to methodology and different drug therapeutic classes under study (Kalyanaram does not consider anti-lipidemics or nasal sprays), the difference may also be attributed to the sample period under consideration. Kalyanaram examines data from 1998 and 1999, when broadcast DTCA was becoming more prevalent and overtaking non-broadcast DTCA, whereas the study by Rosenthal et al. also included time periods from 1996 and 1997 when non-broadcast DTCA was still the primary form of consumer-directed advertising. If it is specifically broadcast DTCA that has a larger impact on sales, then it is not surprising that the aggregated effect may be close to zero in studies that consider DTCA during periods prior to the late 1990 s.
} 
The estimated elasticities of demand and price with respect to DTCA can inform on the counterfactual scenario of what would be the effect on price and sales if broadcast DTCA had not been allowed and had remained zero. Table 7 summarizes the simulation results, which account for the diminishing marginal product of DTCA. The average monthly stock of broadcast DTCA in 2005 was $\$ 8.7$ million among advertised drugs. If broadcast advertising had remained at zero, as in 1994, then total expenditures among the advertised drugs would be approximately 30.1 percent lower. This simulated decrease in expenditures is mostly driven by the impact of broadcast DTCA on sales; about two-thirds of this decrease can be attributed to the reduction in demand and about one-third can be attributed to the reduction in price.

Some estimates also suggest that class-level DTCA may have raised sales for the nonadvertised drugs. Assuming that physicians are prescribing an equally effective drug, this may be a spillover benefit of DTCA in some cases since non-advertised drugs tend to be older and also cost less; mean prices across drug classes weighted by expenditures (based on Table 2) suggest that the price of non-advertised drugs is about 44 percent lower relative to advertised drugs. Accounting for the increase in the total stock of class broadcast DTCA between 1994 and 2005, this reverse substitution may have led to lower total expenditures by about 3.3 percent. Combining this effect with the above-estimated direct positive impact of DTCA on drug demand and prices suggests that overall drug expenditures are higher by about $26.8 \%$ due to the expansion in broadcast DTCA over the sample period.

To place these estimated impacts into context, average monthly drug expenditures of the advertised drugs increased by 156 percent between 1994 and 2005 . Thus, the increase in broadcast DTCA subsequent to the FDA relaxation of the promotion guidelines appears to have been responsible for about 17 to 19 percent of the overall increase, with over two-thirds of this impact being driven by an increase in demand as a result of the DTCA expansion and the 
remainder being driven by the increase in price. ${ }^{24}$ Thus, while DTCA is significant, it has not been the primary force driving the growth in overall prescription drug expenditures.

\footnotetext{
${ }^{24}$ Rosenthal et al. (2003) estimate an overall DTCA elasticity of 0.10 and conclude that between 1998 and 1999 , the increase in DTCA for proton pump inhibitors was responsible for about $17 \%$ of the increase in sales, and about $12 \%$ of drug sales growth for the 25 largest therapeutic classes. This impact is based on the demand effects of DTCA and does not consider the potential role of increasing prices. Their sample period also predated the largest increase in DTCA that occurred subsequent to 1999. If we were to exclude the price effects of DTCA, then our estimates are in the same range. Demand effects of DTCA alone, based on the estimates in Table 4, suggest that the increase in broadcast DTCA between 1994-2005 is responsible for between 12-13 of the overall growth in prescription drug spending.
} 


\section{References}

Berndt, E.R., 2006. The United States experience with direct-to-consumer advertising of prescription drugs: what have we learned? In: Sloan, F.A., Hsieh, C.R. (Eds), Promoting and Coping with Pharmaceutical Innovation: An International Perspective. Cambridge University Press, New York, 2006. pp. 221-252.

Berndt, E., Bui, L., Reiley, D., Urban, G., 1995. Information, Marketing and Pricing in the US Antiulcer Drug Market. American Economic Review 85 (2), 100-105.

Bhattacharya, J., Vogt, G., 2003. A Simple Model of Pharmaceutical Price Dynamics. The Journal of Law and Economics 46 (2), 599-626.

Bradford, W.D., Kleit, A.N. The Impact of Advertising on Statin Drug Adherence and Attaining LDL Cholesterol Goals. Submitted to Journal of Health Economics.

Bradford, W.D., Kleit, A.N., Nietert, P.J., et al., 2006. Effects of Direct-to-Consumer Advertising of Hydroxymethylglutaryl Coenzyme A Reductase Inhibitors on Attainment of LDL-C Goals. Clinical Therapaeutics 28 (12), 2105-2118.

Bradford, W.D., Kleit, A.N., Nietert, P.J., et al. The Effect of Direct to Consumer Television Advertising for Statin Drugs on the Attainment of LDL Goals. Center for Health Economic and Policy Studies Working Papers.

Calfee, J., Winston, C., Stempski, R., 2002. Direct to Consumer Advertising and Cholesterol Lowering Drugs. Journal of Law and Economics 45 (2), 673-690.

Donohue, J.M., Berndt, E.R., Rosenthal, M., Epstein, A.M., Frank, R.G., 2004. Effects of pharmaceutical promotion on adherence to the treatment guidelines for depression. Med Care 42 (12), 1176-85.

Donohue, J.M., Cevasco, M., Rosenthal, M.B., 2007. A Decade of Direct-to-Consumer Advertising of Prescription Drugs. The New England Journal of Medicine 357 (7), 673-668.

Dorfman, R., Steiner, P.O., 1954. Optimal advertising and optimal quality. American Economic Review 44 (5), 826-836.

Families USA, 2003. Out-of-Bounds: Rising Prescription Drug Prices for Seniors. Families USA Foundation Publication No. 03-106 (July 2003). http://www.familiesusa.org/assets/pdfs/Out of Boundsab79.pdf

Frank, R.G., Berndt, E.R., Donohue, J.M., Epstein, A., Rosenthal, M., 2002. Trends in direct-toconsumer advertising of prescription drugs. Kaiser Family Foundation (February 2002). http://www.kff.org/rxdrugs/loader.cfm?url=/commonspot/security/getfile.cfm\&PagelD=14881

Frank, R.G., Salkever, D.S., 1992. Pricing, Patent Loss and the Market For Pharmaceuticals. Southern Economic Journal 59 (1), 165-179.

Grabowski, H.G., Vernon, J.M., 1992. Brand Loyalty, Entry and Price Competition in Pharmaceuticals After the 1984 Drug Act. Journal of Law and Economics 35 (2), 331-350. 
Grossman, M., 1999. The Human Capital Model of the Demand for Health. National Bureau of Economic Research Working Paper 7078.

lizuka, T., 2004. What explains the use of direct to consumer advertising of prescription drugs? Journal of Industrial Economics, 52 (3), 349-379.

lizuka, T., Jin, G.Z., 2005. The Effect of Prescription Drug Advertising on Doctor Visits. Journal of Economics and Management Strategy 14 (3), 701-727.

lizuka, T. Jin, G.Z., 2007. Direct to Consumer Advertising and Prescription Choice. Journal of Industrial Economics 55 (4), 771.

Kalyanaram, G., 2009. The Endogenous Modeling of the Effect of Direct Advertising to Consumers (DTCA) in Prescription Drugs. International Journal of Pharmaceutical and Healthcare Marketing. Forthcoming.

Kalyanaram, G., 2008. The Order of Entry Effect in Prescription (Rx) and Over-the-counter (OTC) Pharmaceutical Drugs. International Journal of Pharmaceutical and Healthcare Marketing 2 (1), 35-46.

Kaul A., Wittink, D., 1995. Empirical Generalizations about the Impact of Advertising on Price Sensitivity and Price. Marketing Science 14 (3) Part 2, G151-G160.

Kravitz, R.L., Epstein, R.M., Feldman, M.D., Franz, C.E., Azari, R., Wilkes, M.S., Hinton, L., Franks, P., 2005 Influence of patients' requests for direct-to-consumer advertised antidepressants: a randomized controlled trial. Journal of the American Medical Association 293 (16), 1995-2002. Erratum in: JAMA 294 (19), 2436.

Leone, R.P., 1995. Generalizing What is Known About Temporal Aggregation and Advertising Carryover. Marketing Science 14 (3), G141-G150.

Lichtenberg, F.R., 2007. Benefits and costs of newer drugs: an update. Managerial and Decision Economics 28 (4-5), 485-490.

Lichtenberg, F.R., Virabhak, S., 2002. Pharmaceutical-embodied Technical Progress, Longevity, and Quality of Life: Drugs as "Equipment for Your Health". NBER Working Paper No. w9351.

Ling, D., Berndt, E., Kyle, M., 2002. Deregulating Direct to Consumer Marketing of Prescription Drug: Effects on Prescription and Over the Counter Product Sales. Journal of Law and Economics 45 (2), 691-723.

Lloyd-Jones, D., et al., 2009. Heart disease and stroke statistics -- 2009 update: a report from the American Heart Association Statistics Committee and Stroke Statistics Subcommittee. Circulation 119 (3), e21-e181.

Locke III, G.R., Talley, N.J., Fett, S.L., Zinsmeister, A.R., Melton III, L.J., 1997. Prevalence and clinical spectrum of gastroesophageal reflux: a population based study in Olmsted County, Minnesota. Gastroenterology 112 (5), 1448-1456.

Mela, C., Gupta, S., Jedidi, K., 1998. Assessing Long-Term Promotional Influences on Market Structure. International Journal of Research in Marketing 15 (2), 89-107. 
National Institute for Health Care Management, 2001. Prescription Drugs and Mass Media Advertising 2000. NIHCM Foundation (November 2001).

http://nihcm.org/ nihcmor/pdf/DTCbrief2001.pdf

Office of the Assistant Secretary for Planning and Evaluation, 2000. Report to the President: Prescription Drug Coverage, Spending, Utilization and Prices. Department of Health and Human Services (April 2000). http://aspe.os.dhhs.gov/health/reports/drugstudy

Rizzo, J., 1999. Advertising and Competition in the Ethical Pharmaceutical Industry: The case of Hypertensive Drugs. Journal of Law and Economics 42 (1), 89-116.

Rosenthal, M., Berndt, E., Donohue, J., Epstein, A., Frank, R., 2003. Demand Effects of Recent Changes in Prescription Drug Promotion. In: Cutler, D.M., Garber, A.M. (Eds), Frontiers in Health Policy Research, vol.6. MIT Press, Cambridge, 2003. pp. 1-26.

Roth, T., 2007. Insomnia: definition, prevalence, etiology, and consequences. Journal of Clinical Sleep Medicine 3 (5) Supplement, S7-S10.

Weissman, J.S., Blumenthal, D., Silk, A.J., et al., 2004. Physicians Report on patient encounters involving direct-to-consumer advertising. Health Affairs (Millwood), Web Exclusives (April 28, 2004), W4-219-233. http://content.healthaffairs.org/cgi/content/full/hlthaff.w4.219v1/DC1 
Figure 1

Total DTC Advertising Expenditures

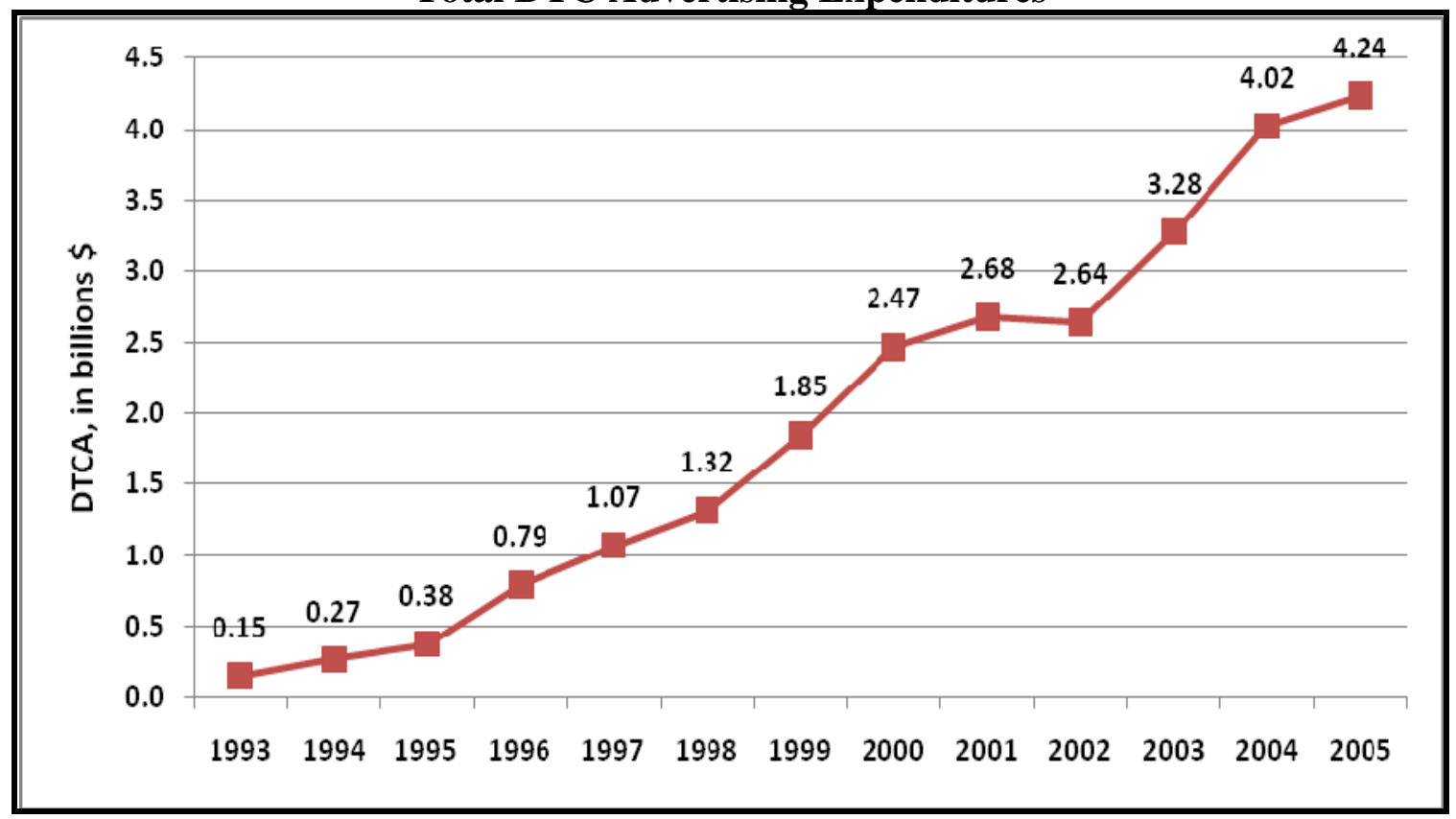

Source: Frank et al. (2002) and Donohue et al. (2007)

Figure 2

Pharmaceutical Promotion - 2005

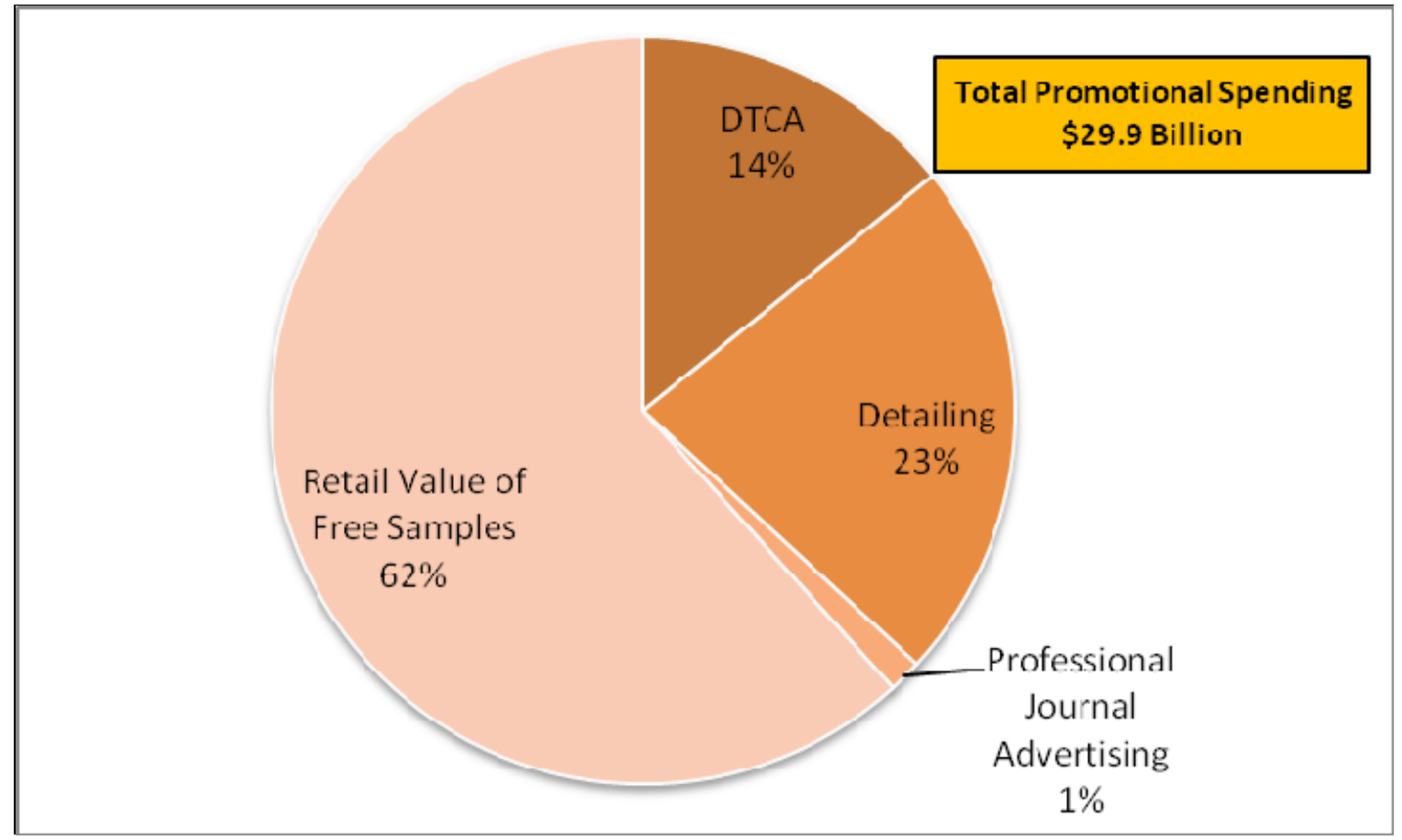

Source: Donohue et al. (2007) 
Figure 3

Total DTC Advertising Expenditures in Sample Therapeutic Classes

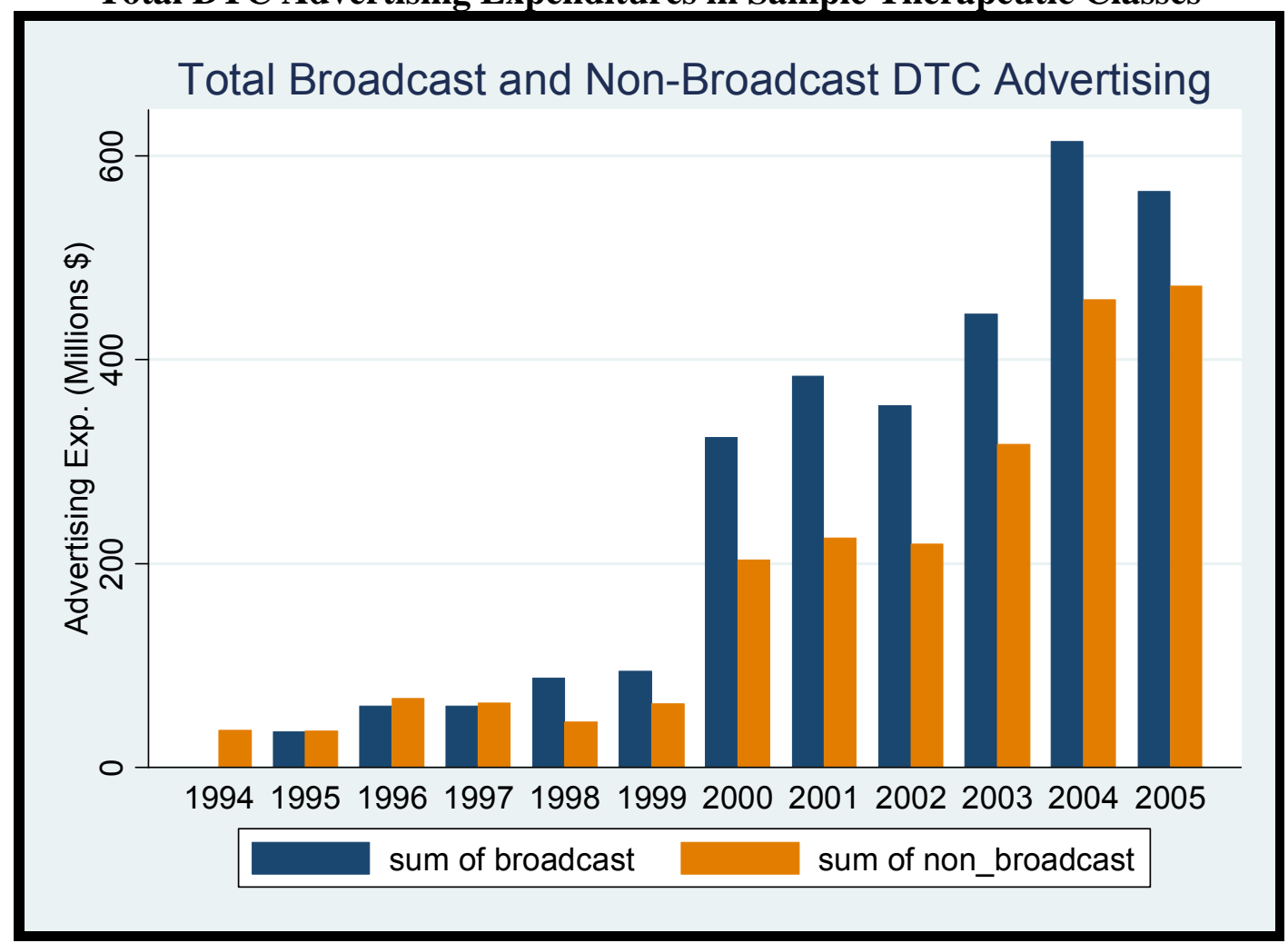

Figure 4

Mean DTC Advertising Expenditures in Sample Therapeutic Classes

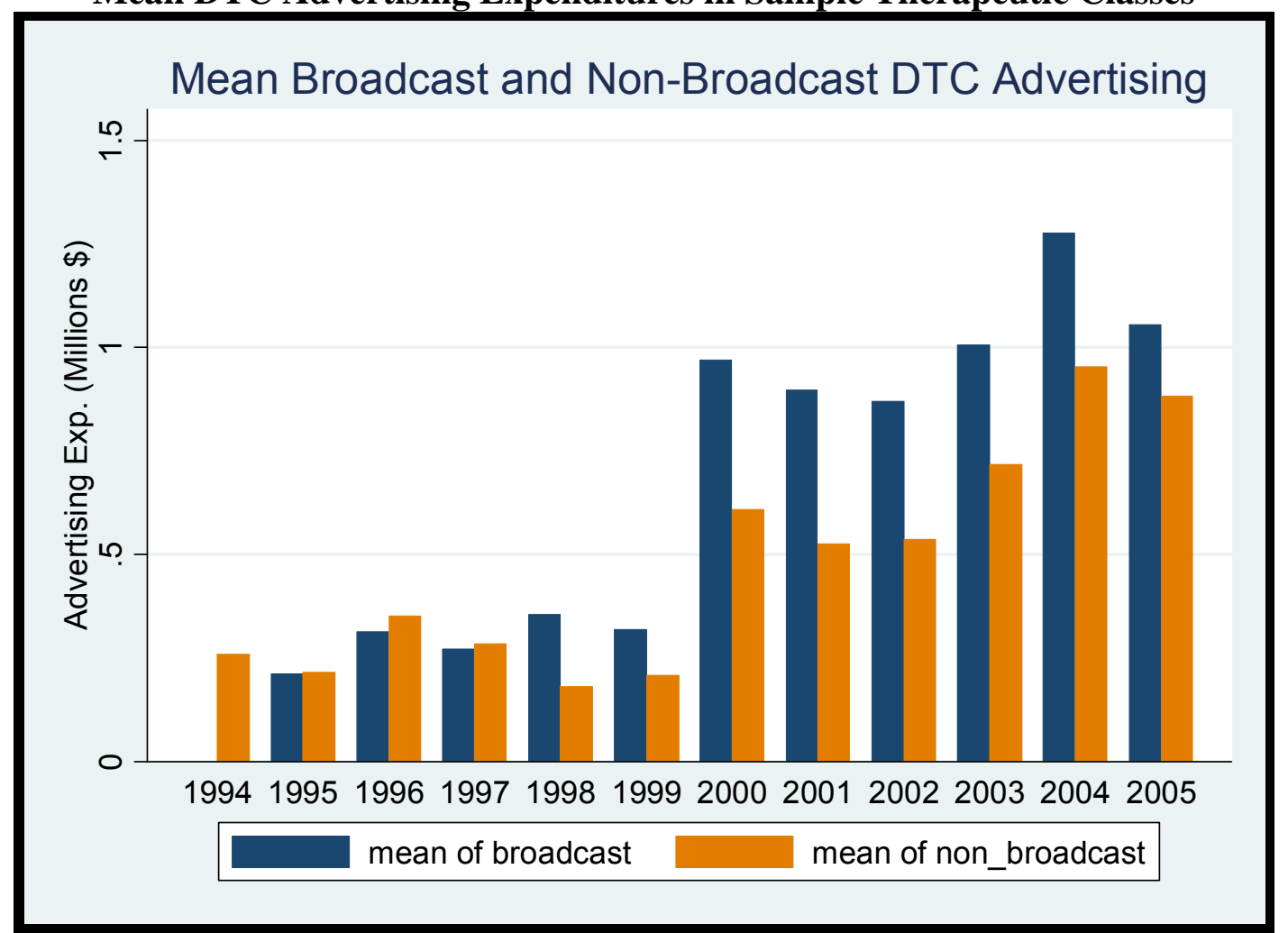


Figure 5

Mean DTC Advertising Expenditures in Sample Therapeutic Classes Balanced Panel of Drugs 1997-2002

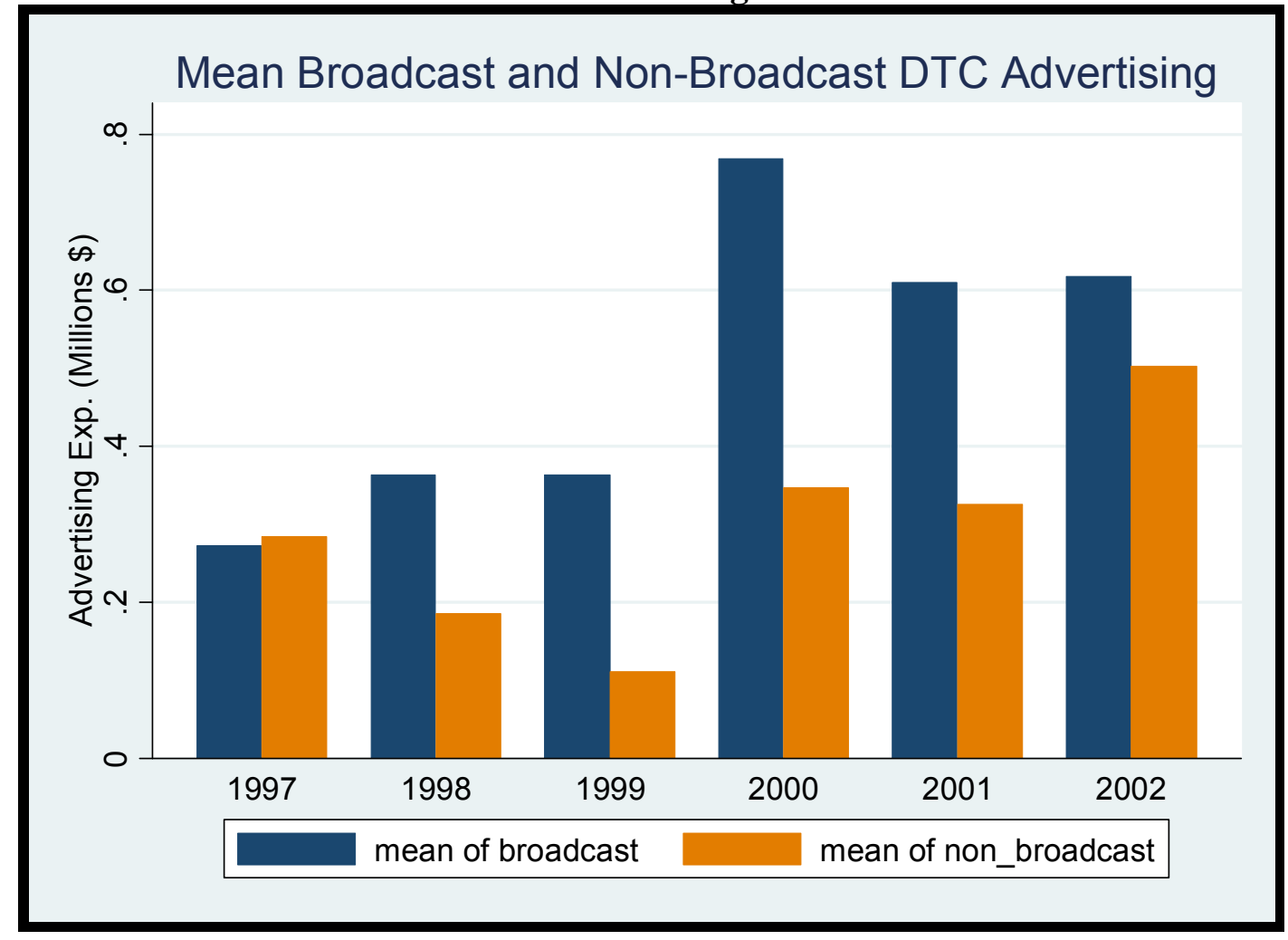

Figure 6

Total Promotional Physician Contacts in Sample Therapeutic Classes

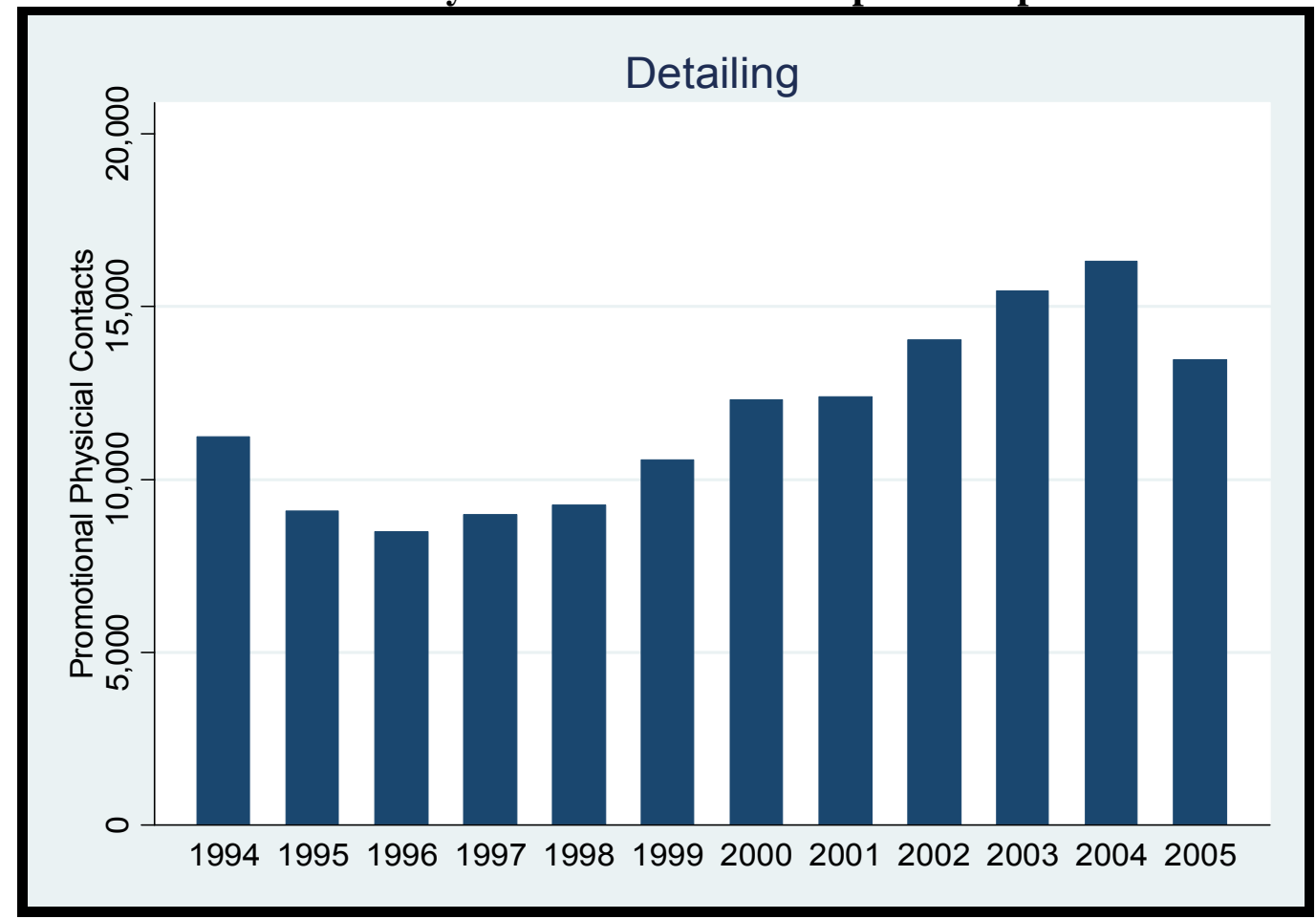


Figure 7

Total Number of Prescription Drugs in Sample Therapeutic Classes

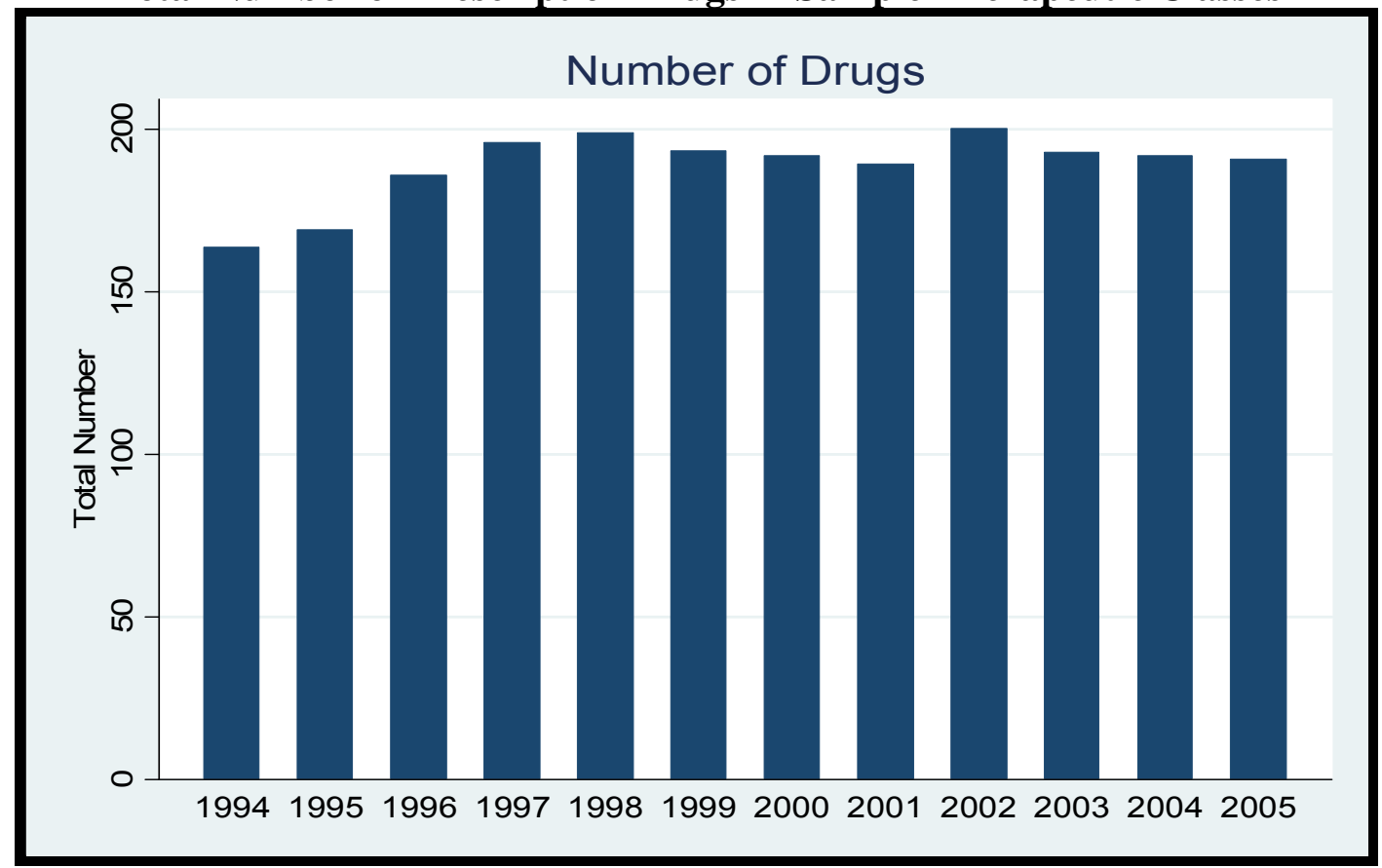


Figure 8 - Life Cycle Trajectory of Drug Prices

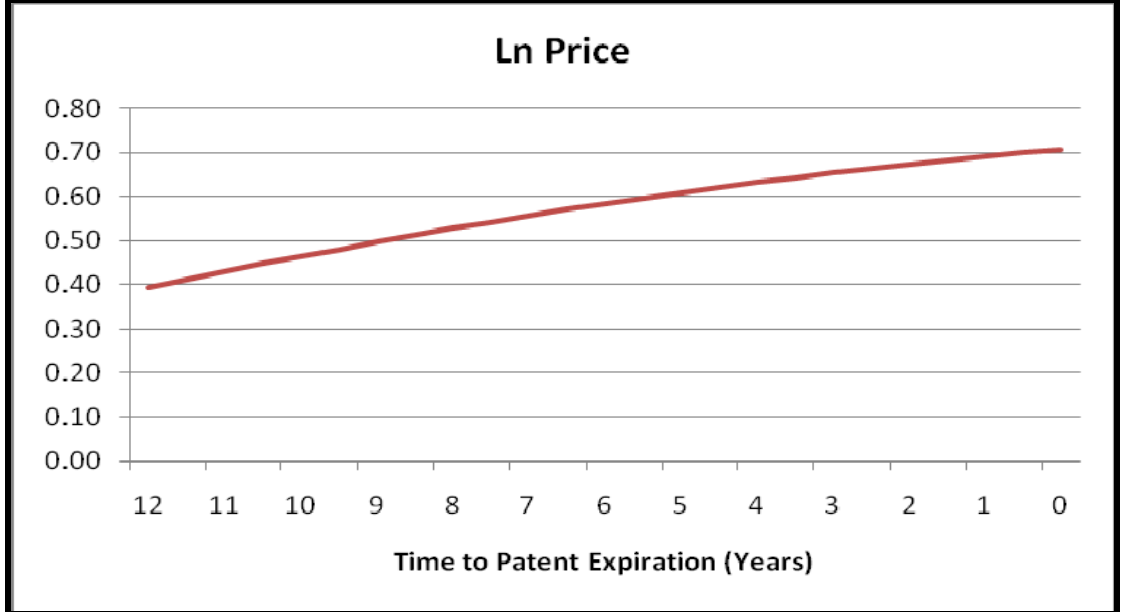

Notes: Based on regression model controlling for Time to Patent Expiration (PE) Time-to-PE squared, and drug and year indicators.

Figure 9 - Life Cycle Trajectory of DTCA

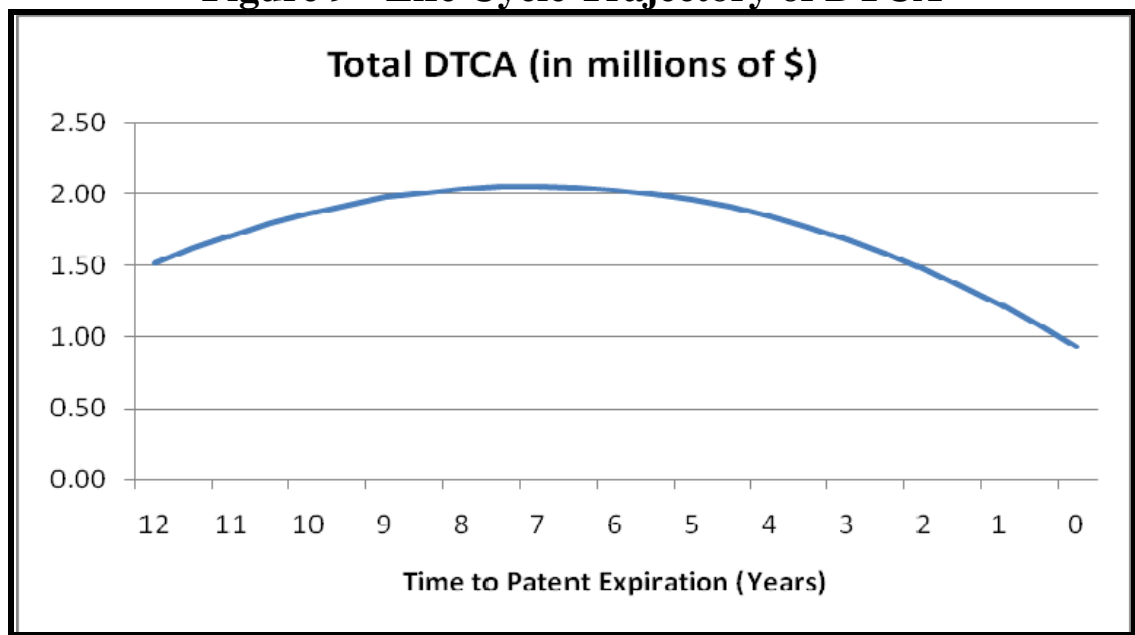

Notes: See Figure8.

Figure 10 - Life Cycle Trajectory of Detailing

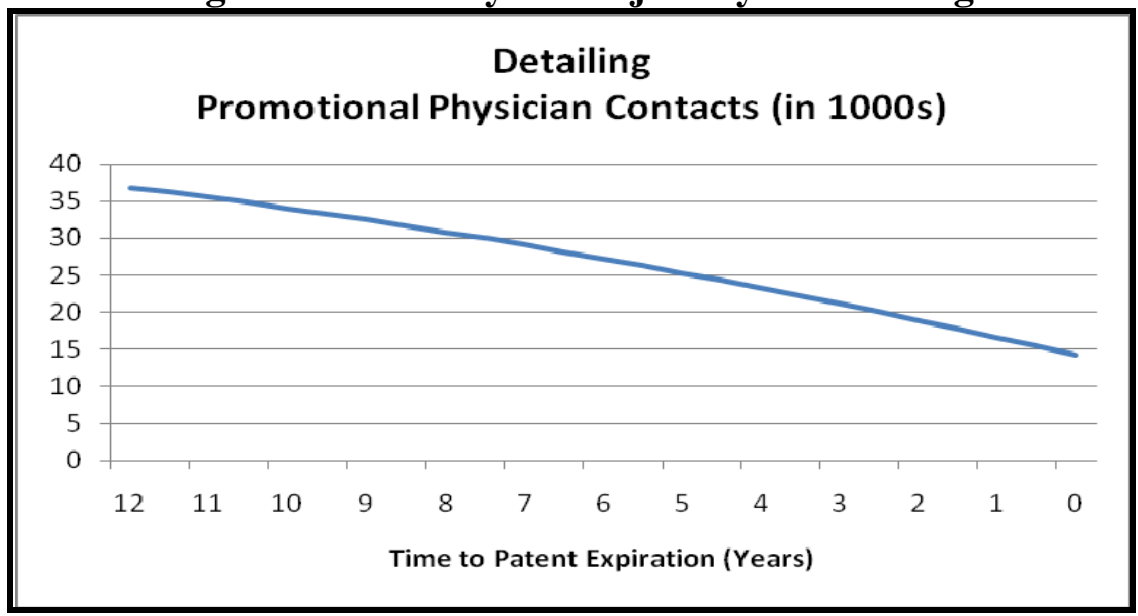

Notes: See Figure 8. 
Table 1

Sample Means - All Therapeutic Classes

Advertised \& Non-Advertised Drugs

\begin{tabular}{|c|c|c|c|}
\hline Variable & Definition & Advertised Drugs & $\begin{array}{l}\text { Non-Advertised } \\
\text { Drugs } \\
\end{array}$ \\
\hline $\begin{array}{l}\text { Broadcast Advertising - } \\
\text { Own }\end{array}$ & $\begin{array}{l}\text { Monthly advertising expenditures of drug } \\
\text { on network and spot television, network } \\
\text { and spot radio, and cable television, in } \\
\text { millions of dollars }\end{array}$ & $\begin{array}{c}0.9456 \\
(2.3907)\end{array}$ & 0 \\
\hline $\begin{array}{l}\text { Non-Broadcast } \\
\text { Advertising - Own }\end{array}$ & $\begin{array}{l}\text { Monthly advertising expenditures of drug } \\
\text { in newspapers, magazines, outdoors, and } \\
\text { internet in millions of dollars }\end{array}$ & $\begin{array}{c}0.6665 \\
(1.63830)\end{array}$ & 0 \\
\hline Total Advertising - Own & $\begin{array}{l}\text { Total monthly advertising expenditures of } \\
\text { drug in all media (television, radio, } \\
\text { newspapers, magazines, outdoors, and } \\
\text { internet), in millions of dollars }\end{array}$ & $\begin{array}{c}1.6121 \\
(3.6470)\end{array}$ & 0 \\
\hline Total Advertising - Cross & $\begin{array}{l}\text { Total monthly advertising expenditures of } \\
\text { all other drugs in the therapeutic class in all } \\
\text { media (television, radio, newspapers, } \\
\text { magazines, outdoors, and internet), in } \\
\text { millions of dollars }\end{array}$ & $\begin{array}{c}10.9565^{* * *} \\
(10.2167)\end{array}$ & $\begin{array}{l}7.4667 \\
(9.0920)\end{array}$ \\
\hline Detailing & $\begin{array}{l}\text { Monthly number of physician contacts for } \\
\text { promotional service associated with the } \\
\text { drug, in thousands, where contact } \\
\text { represents a product-level report of } \\
\text { promotional actions }\end{array}$ & $\begin{array}{c}22.4272 * * * \\
(34.9332)\end{array}$ & $\begin{array}{c}1.1165 \\
(5.2456)\end{array}$ \\
\hline Sampling & $\begin{array}{l}\text { Total extended units of product sampling of } \\
\text { pharmaceutical representatives that are } \\
\text { directed to office-based physicians, in } \\
100,000\end{array}$ & $\begin{array}{c}21.5129 * * * \\
(33.7869)\end{array}$ & $\begin{array}{c}1.0742 \\
(5.9036)\end{array}$ \\
\hline Retail Value of Sampling & $\begin{array}{l}\text { Retail value of the product sampling } \\
\text { activities of pharmaceutical representatives } \\
\text { that are directed to office-based physicians, } \\
\text { in millions of dollars. }\end{array}$ & $\begin{array}{c}4.9953 * * * \\
(8.7388)\end{array}$ & $\begin{array}{c}0.1934 \\
(1.4830) \\
\end{array}$ \\
\hline Drug Price & $\begin{array}{l}\text { Average purchase price of an extended unit } \\
\text { of the drug, based on all doses, in dollars }\end{array}$ & $\begin{array}{c}22.3018 \\
(94.3019) \\
\end{array}$ & $\begin{array}{c}22.2547 \\
(164.9705)\end{array}$ \\
\hline Drug Price - Popular Dose & $\begin{array}{l}\text { Average purchase price of an extended unit } \\
\text { of the drug for the most popular dose, in } \\
\text { dollars }\end{array}$ & $\begin{array}{c}22.5612 \\
(94.8707)\end{array}$ & $\begin{array}{c}22.8961 \\
(167.1513)\end{array}$ \\
\hline Total Sales & $\begin{array}{l}\text { Total sales, in extended units (popular } \\
\text { dose), in millions }\end{array}$ & $\begin{array}{c}22.5850 * * * \\
(27.2128)\end{array}$ & $\begin{array}{c}4.2930 \\
(13.0613) \\
\end{array}$ \\
\hline Total Expenditures & Total sales, in millions of dollars (all doses) & $\begin{array}{l}58.4533 * * * \\
(104.4448)\end{array}$ & $\begin{array}{c}4.9244 \\
(26.0294)\end{array}$ \\
\hline Number of Drugs & $\begin{array}{l}\text { Total number of drugs in the market in the } \\
\text { therapeutic class }\end{array}$ & $\begin{array}{l}89.6506 * * * \\
(100.3017) \\
\end{array}$ & $\begin{array}{c}161.7054 \\
(113.3101)\end{array}$ \\
\hline Time to Patent Expiration & $\begin{array}{l}\text { Fractional number of years to patent } \\
\text { expiration }\end{array}$ & $\begin{array}{c}7.3371 * * * \\
(7.3747)\end{array}$ & $\begin{array}{l}-1.1773 \\
(8.8991)\end{array}$ \\
\hline \multicolumn{2}{|l|}{ Observations } & 4499 & 14125 \\
\hline
\end{tabular}

Notes: Standard deviations are in parentheses. Number of observations listed represents the maximum sample size. For some variables, the actual sample size is less due to missing information. Asterisks denote that the difference in means between the advertised and the non-advertised drugs is statistically significant as follows: $* * * \mathrm{p}$-value $\leq 0.01$, ** $0.01<\mathrm{p}$-value $\leq 0.05,0.05<\mathrm{p}$-value $\leq 0.10$. 
Table 2

\section{Sample Means - By Therapeutic Class Advertised \& Non-Advertised Drugs}

\begin{tabular}{|c|c|c|c|c|}
\hline Sample & Advertised Drugs & $\begin{array}{l}\text { Non-Advertised } \\
\text { Drugs }\end{array}$ & Advertised Drugs & $\begin{array}{c}\text { Non-Advertised } \\
\text { Drugs }\end{array}$ \\
\hline & \multicolumn{2}{|c|}{ Analgesics / Anti-Arthritic } & \multicolumn{2}{|c|}{ Anti-Lipidemics } \\
\hline $\begin{array}{l}\text { Broadcast Advertising - } \\
\text { Own }\end{array}$ & $\begin{array}{l}0.7479 \\
(1.6777)\end{array}$ & 0 & $\begin{array}{c}0.8600 \\
(2.2462)\end{array}$ & 0 \\
\hline $\begin{array}{l}\text { Non-Broadcast Advertising - } \\
\text { Own }\end{array}$ & $\begin{array}{c}0.6254 \\
(1.5761)\end{array}$ & 0 & $\begin{array}{c}0.7952 \\
(1.6862)\end{array}$ & 0 \\
\hline $\begin{array}{l}\text { Total Advertising - } \\
\text { Own }\end{array}$ & $\begin{array}{c}1.3733 \\
(2.8458)\end{array}$ & 0 & $\begin{array}{c}1.6552 \\
(3.4982)\end{array}$ & 0 \\
\hline $\begin{array}{l}\text { Total Advertising - } \\
\text { Cross }\end{array}$ & $\begin{array}{l}11.8383 \\
(8.5711)\end{array}$ & $\begin{array}{c}9.5219 \\
(8.8074)\end{array}$ & $\begin{array}{c}12.9734 \\
(12.0214)\end{array}$ & $\begin{array}{c}16.3281 \\
(12.6944)\end{array}$ \\
\hline Detailing & $\begin{array}{c}30.1012 * * * \\
(50.3816)\end{array}$ & $\begin{array}{c}0.9705 \\
(4.8349) \\
\end{array}$ & $\begin{array}{c}32.0736 * * * \\
(32.9552)\end{array}$ & $\begin{array}{c}6.6156 \\
(8.7336) \\
\end{array}$ \\
\hline Retail Value of Sampling & $\begin{array}{c}4.4338 * * * \\
(7.8949) \\
\end{array}$ & $\begin{array}{c}0.0765 \\
(0.4189)\end{array}$ & $\begin{array}{c}7.2998 * * * \\
(9.9996) \\
\end{array}$ & $\begin{array}{c}0.6961 \\
(1.3145)\end{array}$ \\
\hline Drug Price & $\begin{array}{l}78.5197 * * * \\
(171.1242)\end{array}$ & $\begin{array}{c}40.8757 \\
(223.5594)\end{array}$ & $\begin{array}{c}1.9043 * * * \\
(0.9175)\end{array}$ & $\begin{array}{c}1.3557 \\
(0.5425)\end{array}$ \\
\hline Drug Price - Popular Dose & $\begin{array}{l}79.3317 * * * \\
(172.0329)\end{array}$ & $\begin{array}{c}42.0381 \\
(226.4428)\end{array}$ & $\begin{array}{l}1.9552 * * * \\
(1.0434)\end{array}$ & $\begin{array}{c}1.4387 \\
(0.5944)\end{array}$ \\
\hline Total Expenditures & $\begin{array}{l}51.6751^{* * *} \\
(69.6359)\end{array}$ & $\begin{array}{c}3.2506 \\
(8.5421)\end{array}$ & $\begin{array}{l}93.8417 * * * \\
(149.3487)\end{array}$ & $\begin{array}{c}11.5344 \\
(19.9683)\end{array}$ \\
\hline Number of Drugs & $\begin{array}{l}268.8229 \\
(11.5805)\end{array}$ & $\begin{array}{l}268.3067 \\
(13.9094)\end{array}$ & $\begin{array}{l}30.9782 * * \\
(2.2946)\end{array}$ & $\begin{array}{l}31.2479 \\
(2.3791)\end{array}$ \\
\hline Time to Patent Expiration & $\begin{array}{l}7.7971 * * * \\
(9.4290)\end{array}$ & $\begin{array}{c}1.3686 \\
(8.6735)\end{array}$ & $\begin{array}{l}9.0854 * * * \\
(4.5939)\end{array}$ & $\begin{array}{c}2.6100 \\
(8.4438)\end{array}$ \\
\hline Observations & 1067 & 7453 & 1236 & 468 \\
\hline \multirow[t]{2}{*}{ Sample } & Advertised Drugs & $\begin{array}{c}\text { Non-Advertised } \\
\text { Drugs }\end{array}$ & Advertised Drugs & $\begin{array}{l}\text { Non-Advertised } \\
\text { Drugs }\end{array}$ \\
\hline & \multicolumn{2}{|c|}{ Gastrointestinal } & \multicolumn{2}{|c|}{ Hypnotics / Sleep-Aids } \\
\hline $\begin{array}{l}\text { Broadcast Advertising - } \\
\text { Own }\end{array}$ & $\begin{array}{l}1.0488 \\
(2.6516)\end{array}$ & 0 & $\begin{array}{c}1.3898 \\
(3.2754)\end{array}$ & 0 \\
\hline $\begin{array}{l}\text { Non-Broadcast Advertising - } \\
\text { Own }\end{array}$ & $\begin{array}{c}0.6506 \\
(1.6873) \\
\end{array}$ & 0 & $\begin{array}{c}0.3953 \\
(1.2647) \\
\end{array}$ & 0 \\
\hline $\begin{array}{l}\text { Total Advertising - } \\
\text { Own }\end{array}$ & $\begin{array}{c}1.6995 \\
(4.0278)\end{array}$ & 0 & $\begin{array}{c}1.7852 \\
(4.3034)\end{array}$ & 0 \\
\hline $\begin{array}{l}\text { Total Advertising - } \\
\text { Cross }\end{array}$ & $\begin{array}{c}10.2577 * * \\
(9.5684)\end{array}$ & $\begin{array}{c}9.5033 \\
(9.7256)\end{array}$ & $\begin{array}{c}3.7361 * * * \\
(8.2382)\end{array}$ & $\begin{array}{c}1.1011 \\
(3.8043)\end{array}$ \\
\hline Detailing & $\begin{array}{c}13.5168 * * * \\
(23.5777)\end{array}$ & $\begin{array}{c}2.3066 \\
(8.2199)\end{array}$ & $\begin{array}{c}11.9540 * * * \\
(12.2929)\end{array}$ & 0 \\
\hline Retail Value of Sampling & $\begin{array}{c}4.4535 * * * \\
(8.6145)\end{array}$ & $\begin{array}{c}0.8814 \\
(3.6553)\end{array}$ & $\begin{array}{c}0.6416^{* * *} \\
(0.8404)\end{array}$ & 0 \\
\hline Drug Price & $\begin{array}{c}2.1721 * * * \\
(3.9264)\end{array}$ & $\begin{array}{c}1.0710 \\
(1.2753) \\
\end{array}$ & $\begin{array}{c}1.9900^{* * * *} \\
(0.4317)\end{array}$ & $\begin{array}{c}0.4340 \\
(1.0381) \\
\end{array}$ \\
\hline Drug Price - Popular Dose & $\begin{array}{c}2.2223 * * * \\
(3.9126)\end{array}$ & $\begin{array}{c}1.0850 \\
(1.3317)\end{array}$ & $\begin{array}{c}2.0665^{* * *} \\
(0.4134)\end{array}$ & $\begin{array}{c}0.4576 \\
(1.1168)\end{array}$ \\
\hline Total Expenditures & $\begin{array}{c}42.7201 * * * \\
(85.2361)\end{array}$ & $\begin{array}{c}18.8953 \\
(63.5884) \\
\end{array}$ & $\begin{array}{c}36.3989 * * * \\
(51.1029)\end{array}$ & $\begin{array}{c}0.2934 \\
(0.8780) \\
\end{array}$ \\
\hline Number of Drugs & $\begin{array}{c}33.2792 * * * \\
(7.9344)\end{array}$ & $\begin{array}{l}32.1968 \\
(6.5670)\end{array}$ & $\begin{array}{c}48.0316^{* * *} \\
(2.6467)\end{array}$ & $\begin{array}{l}49.3601 \\
(2.4584)\end{array}$ \\
\hline Time to Patent Expiration & $\begin{array}{c}4.4481 \\
(6.1320)\end{array}$ & $\begin{array}{c}4.5906 \\
(4.4995)\end{array}$ & $\begin{array}{c}15.0589 * * * \\
(6.3885)\end{array}$ & $\begin{array}{c}-9.2652 \\
(4.6731)\end{array}$ \\
\hline Observations & 1848 & 2124 & 348 & 4080 \\
\hline
\end{tabular}

Notes: See Table 1 
Table 3

Prescription Drug Sales

Advertised and Non-Advertised Drugs under Patent

\begin{tabular}{|c|c|c|c|c|c|c|c|c|}
\hline Dependent & \multicolumn{8}{|c|}{ Ln Prescription Drug Sales } \\
\hline Model & 1 & 2 & 3 & 4 & 5 & 6 & 7 & 8 \\
\hline Sample & Advertised & $\begin{array}{c}\text { Non- } \\
\text { Advertised }\end{array}$ & "Advertised & $\begin{array}{c}\text { Non- } \\
\text { Advertised }\end{array}$ & Advertised & $\begin{array}{c}\text { Non- } \\
\text { Advertised }\end{array}$ & Advertised & $\begin{array}{c}\text { Non- } \\
\text { Advertised }\end{array}$ \\
\hline Ln Price & $\begin{array}{c}-0.6677 * * * \\
(0.0424)\end{array}$ & $\begin{array}{c}-0.7269 * * * \\
(0.0307)\end{array}$ & $\begin{array}{c}-0.6417 * * * \\
(0.0429)\end{array}$ & $\begin{array}{c}-0.7276^{* * * *} \\
(0.0307)\end{array}$ & $\begin{array}{c}-0.6812 * * * \\
(0.0420)\end{array}$ & $\begin{array}{c}-0.7283 * * * \\
(0.0310)\end{array}$ & $\begin{array}{c}-0.6716^{* * *} \\
(0.0422)\end{array}$ & $\begin{array}{c}-0.7255^{* * * *} \\
(0.0305)\end{array}$ \\
\hline $\begin{array}{l}\text { Own Total } \\
\text { Advertising Stock }\end{array}$ & $\begin{array}{c}0.0125 * * * \\
(0.0017)\end{array}$ & - & $\begin{array}{c}0.0177 * * * \\
(0.0018)\end{array}$ & - & $\begin{array}{c}0.0161 * * * \\
(0.0018)\end{array}$ & - & $\begin{array}{c}0.0121 * * * \\
(0.0017)\end{array}$ & - \\
\hline $\begin{array}{l}\text { Own Total Adv. } \\
\text { Stock - Square }\end{array}$ & $\begin{array}{l}-0.0001 * * * \\
(0.00001)\end{array}$ & - & $\begin{array}{c}-0.0001 * * * \\
(0.00002)\end{array}$ & - & $\begin{array}{c}-0.0001 * * * \\
(0.00001)\end{array}$ & - & $\begin{array}{c}-0.0001 * * * \\
(0.00001)\end{array}$ & - \\
\hline & {$[\varepsilon=0.132]$} & & {$[\varepsilon=0.185]$} & & {$[\varepsilon=0.167]$} & & {$[\varepsilon=0.127]$} & \\
\hline $\begin{array}{l}\text { Cross Total } \\
\text { Advertising Stock }\end{array}$ & $\begin{array}{c}-0.0019 * * \\
(0.0009)\end{array}$ & $\begin{array}{c}0.0040 * * * \\
(0.0014)\end{array}$ & $\begin{array}{c}-0.0033 * * * \\
(0.0008)\end{array}$ & $\begin{array}{c}0.0039 * * * \\
(0.0013)\end{array}$ & $\begin{array}{l}-0.0022^{*} \\
(0.0011)\end{array}$ & $\begin{array}{l}0.0035^{* *} \\
(0.0014)\end{array}$ & $\begin{array}{c}-0.0019 * * \\
(0.0009)\end{array}$ & $\begin{array}{c}0.0018 \\
(0.0012)\end{array}$ \\
\hline $\begin{array}{l}\text { Cross Total Adv. } \\
\text { Stock - Square }\end{array}$ & $\begin{array}{c}0.000004 \\
(0.000003)\end{array}$ & $\begin{array}{l}-0.00001^{* *} \\
(0.00001)\end{array}$ & $\begin{array}{l}0.00001 * * * \\
(0.000003)\end{array}$ & $\begin{array}{l}-0.00001^{* *} \\
(0.000005)\end{array}$ & $\begin{array}{c}0.00001 \\
(0.000004)\end{array}$ & $\begin{array}{l}-0.00001^{*} \\
(0.00001)\end{array}$ & $\begin{array}{c}0.000004 \\
(0.000004)\end{array}$ & $\begin{array}{l}-0.000004 \\
(0.000005)\end{array}$ \\
\hline & {$[\varepsilon=-0.099]$} & {$[\varepsilon=0.171]$} & {$[\varepsilon=-0.134]$} & {$[\varepsilon=0.165$} & {$[\varepsilon=-0.094]$} & {$[\varepsilon=0.150]$} & {$[\varepsilon=-0.094]$} & {$[\varepsilon=0.091]$} \\
\hline Detailing & $\begin{array}{c}0.0186 * * * \\
(0.0022) \\
\end{array}$ & $\begin{array}{c}0.0063^{* *} \\
(0.0026) \\
\end{array}$ & - & - & - & - & $\begin{array}{c}0.0161^{* * * *} \\
(0.0021)\end{array}$ & $\begin{array}{c}0.0048 \\
(0.0036) \\
\end{array}$ \\
\hline Detailing - Square & $\begin{array}{c}-0.0001 * * * \\
(0.0000)\end{array}$ & $\begin{array}{l}-0.0001^{*} \\
(0.00004)\end{array}$ & - & - & - & - & $\begin{array}{c}-0.00005^{* * * *} \\
(0.00001)\end{array}$ & $\begin{array}{l}-0.00002 \\
(0.0001)\end{array}$ \\
\hline & {$[\varepsilon=0.511]$} & {$[\varepsilon=0.019]$} & & & & & {$[\varepsilon=0.554]$} & {$[\varepsilon=0.016]$} \\
\hline Sampling & - & - & $\begin{array}{c}0.0141 * * * \\
(0.0016)\end{array}$ & $\begin{array}{l}0.0024 * * \\
(0.0012)\end{array}$ & - & - & - & - \\
\hline Sampling - Square & - & - & $\begin{array}{l}-0.00004 * * * \\
(0.000005)\end{array}$ & $\begin{array}{l}-0.00002 \\
(0.00001)\end{array}$ & - & - & - & - \\
\hline & & & {$[\varepsilon=0.341]$} & {$[\varepsilon=0.007]$} & & & & \\
\hline $\begin{array}{l}\text { Retail Value of } \\
\text { Sampling }\end{array}$ & - & - & - & - & $\begin{array}{c}0.0493 * * * \\
(0.0068)\end{array}$ & $\begin{array}{l}-0.0009 \\
(0.0074)\end{array}$ & $\begin{array}{c}0.0254 * * * \\
(0.0051)\end{array}$ & $\begin{array}{l}-0.0123 \\
(0.0094)\end{array}$ \\
\hline $\begin{array}{l}\text { Retail Value of } \\
\text { Sampling - Square }\end{array}$ & - & - & - & - & $\begin{array}{c}-0.0006^{* * * *} \\
(0.0001)\end{array}$ & $\begin{array}{c}0.0002 \\
(0.0002)\end{array}$ & $\begin{array}{c}-0.0004 * * * \\
(0.0001)\end{array}$ & $\begin{array}{l}0.0005^{*} \\
(0.0003)\end{array}$ \\
\hline & & & & & {$[\varepsilon=0.276]$} & $\begin{array}{c}{[\varepsilon=-} \\
0.0004]\end{array}$ & {$[\varepsilon=0.136]$} & {$[\varepsilon=-0.008]$} \\
\hline $\begin{array}{l}\text { Time to Patent } \\
\text { Expiration (PE) }\end{array}$ & $\begin{array}{c}0.2934 * * * \\
(0.0354)\end{array}$ & $\begin{array}{c}0.2932 * * * \\
(0.0405)\end{array}$ & $\begin{array}{c}0.3330 * * * \\
(0.0276)\end{array}$ & $\begin{array}{c}0.1997 * * * \\
(0.0256)\end{array}$ & $\begin{array}{c}0.2910 * * * \\
(0.0371)\end{array}$ & $\begin{array}{c}0.2973 * * * \\
(0.0527)\end{array}$ & $\begin{array}{c}0.3030 * * * \\
(0.0340)\end{array}$ & $\begin{array}{c}0.9148 * * * \\
(0.3397)\end{array}$ \\
\hline $\begin{array}{l}\text { Time to PE } \\
\text { Squared }\end{array}$ & $\begin{array}{c}0.0015 \\
(0.0014)\end{array}$ & $\begin{array}{c}-0.0112 * * * \\
(0.0017)\end{array}$ & $\begin{array}{c}0.0004 \\
(0.0011)\end{array}$ & $\begin{array}{c}-0.0114^{* * *} \\
(0.0017)\end{array}$ & $\begin{array}{c}0.0022 \\
(0.0015)\end{array}$ & $\begin{array}{c}-0.0113^{* * *} \\
(0.0023)\end{array}$ & $\begin{array}{c}0.0011 \\
(0.0013)\end{array}$ & $\begin{array}{c}-0.0124 * * * \\
(0.0015)\end{array}$ \\
\hline Number of Drugs & $\begin{array}{c}0.0028 \\
(0.0030)\end{array}$ & $\begin{array}{c}-0.0065^{* * * *} \\
(0.0020)\end{array}$ & $\begin{array}{c}0.0042 \\
(0.0030)\end{array}$ & $\begin{array}{c}-0.0065^{* * *} \\
(0.0020)\end{array}$ & $\begin{array}{c}0.0032 \\
(0.0034)\end{array}$ & $\begin{array}{c}-0.0066^{* * *} \\
(0.0020)\end{array}$ & $\begin{array}{c}0.0024 \\
(0.0030)\end{array}$ & $\begin{array}{c}-0.0067 * * * \\
(0.0020)\end{array}$ \\
\hline Drug Indicators & Yes*** & Yes*** & Yes*** & Yes*** & Yes $* * *$ & Yes*** & Yes $* * *$ & Yes*** \\
\hline Month Indicators & Yes*** & Yes*** & Yes*** & Yes*** & Yes*** & Yes*** & Yes*** & Yes*** \\
\hline Year Indicators & Yes*** & Yes*** & Yes*** & Yes*** & Yes*** & Yes*** & Yes*** & Yes*** \\
\hline R-Squared & 0.993 & 0.984 & 0.994 & 0.985 & 0.994 & 0.983 & 0.994 & 0.986 \\
\hline Observations & 2048 & 3200 & 2048 & 3200 & 2048 & 3200 & 2048 & 3200 \\
\hline
\end{tabular}

Notes: Standard errors are corrected for first-order autocorrelation and panel-specific heteroscedasticity, and are reported in

parentheses. Elasticity estimates, evaluated at the sample mean, are reported in brackets underneath the relevant promotion measure,

where applicable. Advertised drugs denote prescription drugs which have ever undertaken direct-to-consumer advertising at any point over the sample period (1994-2005). Non-advertised drugs denote prescription drugs which have never undertaken DTCA over the sample period. Asterisks denote statistical significance as follows: ${ }^{* * *}$ p-value $\leq 0.01, * * 0.01<p$-value $\leq 0.05,0.05<p$-value $\leq 0.10$. 
Table 4

Prescription Drug Sales

Advertised Drugs

\begin{tabular}{|c|c|c|c|c|c|c|}
\hline Dependent Variable & \multicolumn{6}{|c|}{ Ln Prescription Drug Sales } \\
\hline Model & 1 & 2 & 3 & 4 & 5 & 6 \\
\hline Sample & All & All & $1994-2002$ & $1997-2002$ & $\begin{array}{c}1997 \text { - } 2002 \\
\text { Periods } \\
\text { Under Patent }\end{array}$ & $\begin{array}{c}1997-2002 \\
\text { Balanced Panel } \\
\text { Periods } \\
\text { Under Patent }\end{array}$ \\
\hline $\begin{array}{l}\text { Own Total Broadcast } \\
\text { Advertising Stock }\end{array}$ & $\begin{array}{l}0.0103 * * * \\
(0.00380\end{array}$ & $\begin{array}{c}0.0136 * * * \\
(0.0032) \\
\end{array}$ & $\begin{array}{c}0.0297 * * * \\
(0.0041)\end{array}$ & $\begin{array}{c}0.0283 * * * \\
(0.0042)\end{array}$ & $\begin{array}{c}0.0262 * * * \\
(0.0045) \\
\end{array}$ & $\begin{array}{c}0.0302 * * * \\
(0.0073)\end{array}$ \\
\hline $\begin{array}{l}\text { Own Total Broadcast Adv. } \\
\text { Stock - Square }\end{array}$ & $\begin{array}{l}-0.0001 \\
(0.0001)\end{array}$ & $\begin{array}{c}-0.0001 * * * \\
(0.0001)\end{array}$ & $\begin{array}{c}-0.0004 * * * \\
(0.0001) \\
\end{array}$ & $\begin{array}{c}-0.0004 * * * \\
(0.0001) \\
\end{array}$ & $\begin{array}{c}-0.0004 * * * \\
(0.0001) \\
\end{array}$ & $\begin{array}{c}-0.0006 * * * \\
(0.0002) \\
\end{array}$ \\
\hline & {$[\varepsilon=0.056]$} & {$[\varepsilon=0.070]$} & {$[\varepsilon=0.107]$} & {$[\varepsilon=0.113]$} & {$[\varepsilon=0.103]$} & {$[\varepsilon=0.087]$} \\
\hline $\begin{array}{l}\text { Own Total Non-Broadcast } \\
\text { Adv. Stock }\end{array}$ & $\begin{array}{c}0.0217 * * * \\
(0.0043)\end{array}$ & $\begin{array}{c}0.0134 * * * \\
(0.0040)\end{array}$ & $\begin{array}{c}0.0204 * * * \\
(0.0053)\end{array}$ & $\begin{array}{l}0.0107 * \\
(0.0062)\end{array}$ & $\begin{array}{c}0.0196 * * * \\
(0.0066)\end{array}$ & $\begin{array}{c}0.0112 \\
(0.0127)\end{array}$ \\
\hline $\begin{array}{l}\text { Own Total Non-Broadcast } \\
\text { Adv. Stock - Square }\end{array}$ & $\begin{array}{l}-0.0003 * \\
(0.0001)\end{array}$ & $\begin{array}{l}-0.0002 \\
(0.0001)\end{array}$ & $\begin{array}{c}-0.0003 * * * \\
(0.0001)\end{array}$ & $\begin{array}{l}-0.0001 \\
(0.0001)\end{array}$ & $\begin{array}{c}-0.0002 * * \\
(0.0001)\end{array}$ & $\begin{array}{l}-0.0001 \\
(0.0004)\end{array}$ \\
\hline & {$[\varepsilon=0.084]$} & {$[\varepsilon=0.053]$} & {$[\varepsilon=0.057]$} & {$[\varepsilon=0.034]$} & {$[\varepsilon=0.065]$} & {$[\varepsilon=0.026]$} \\
\hline $\begin{array}{l}\text { Cross Total Advertising } \\
\text { Stock }\end{array}$ & $\begin{array}{l}-0.0013 \\
(0.0011)\end{array}$ & $\begin{array}{l}-0.0001 \\
(0.0011)\end{array}$ & $\begin{array}{c}0.0019 \\
(0.0017) \\
\end{array}$ & $\begin{array}{c}0.0016 \\
(0.0016)\end{array}$ & $\begin{array}{c}0.0019 \\
(0.0015)\end{array}$ & $\begin{array}{c}0.0016 \\
(0.0018)\end{array}$ \\
\hline $\begin{array}{l}\text { Cross Total Adv. Stock - } \\
\text { Square }\end{array}$ & $\begin{array}{c}0.000004 \\
(0.000004)\end{array}$ & $\begin{array}{l}-0.000001 \\
(0.000004)\end{array}$ & $\begin{array}{l}-0.00001 \\
(0.00001)\end{array}$ & $\begin{array}{l}-0.000002 \\
(0.00001) \\
\end{array}$ & $\begin{array}{l}-0.00001 \\
(0.00001)\end{array}$ & $\begin{array}{l}-0.00001 \\
(0.00001)\end{array}$ \\
\hline & {$[\varepsilon=-0.056]$} & {$[\varepsilon=-0.016]$} & {$[\varepsilon=0.050]$} & {$[\varepsilon=0.062]$} & {$[\varepsilon=0.045]$} & {$[\varepsilon=0.039]$} \\
\hline Sampling & $\begin{array}{c}0.0126^{* * *} \\
(0.0014)\end{array}$ & $\begin{array}{c}0.0051 * * * \\
(0.0012)\end{array}$ & $\begin{array}{c}0.0035^{* * * *} \\
(0.0011)\end{array}$ & $\begin{array}{c}0.0031^{* * * *} \\
(0.0011)\end{array}$ & $\begin{array}{c}0.0038^{* * *} \\
(0.0011)\end{array}$ & $\begin{array}{l}0.0032 * * \\
(0.0014)\end{array}$ \\
\hline Sampling - Square & $\begin{array}{l}-0.00004 * * * \\
(0.000004)\end{array}$ & $\begin{array}{l}-0.00002^{* * *} \\
(0.000004)\end{array}$ & $\begin{array}{l}-0.00001 * * \\
(0.000005)\end{array}$ & $\begin{array}{l}-0.00001 \\
(0.00001)\end{array}$ & $\begin{array}{l}-0.00001 * * \\
(0.00001)\end{array}$ & $\begin{array}{l}-0.00001 \\
(0.00001)\end{array}$ \\
\hline & {$[\varepsilon=0.243]$} & {$[\varepsilon=0.094]$} & {$[\varepsilon=0.094]$} & {$[\varepsilon=0.056]$} & {$[\varepsilon=0.076]$} & {$[\varepsilon=0.055]$} \\
\hline Detailing & - & $\begin{array}{c}0.0157 * * * \\
(0.0021)\end{array}$ & - & - & - & - \\
\hline Detailing - Square & - & $\begin{array}{l}-0.00005^{* * *} \\
(0.00001)\end{array}$ & - & - & - & - \\
\hline & & {$[\varepsilon=0.354]$} & & & & \\
\hline $\begin{array}{l}\text { Time to Patent Expiration } \\
\text { (PE) }\end{array}$ & $\begin{array}{c}-0.1019 * * * \\
(0.0243)\end{array}$ & $\begin{array}{c}-0.1409 * * * \\
(0.0271)\end{array}$ & $\begin{array}{c}0.0008 \\
(0.0197)\end{array}$ & $\begin{array}{l}-0.0094 \\
(0.0168)\end{array}$ & $\begin{array}{c}0.2669 * * * \\
(0.0446)\end{array}$ & $\begin{array}{l}0.3768 * * * \\
(0.0575)\end{array}$ \\
\hline Time to PE Squared & $\begin{array}{c}-0.0064 * * * \\
(0.0009)\end{array}$ & $\begin{array}{c}-0.0069 * * * \\
(0.0010)\end{array}$ & $\begin{array}{c}-0.0059 * * * \\
(0.0012)\end{array}$ & $\begin{array}{c}-0.0041^{* * *} \\
(0.0014)\end{array}$ & $\begin{array}{c}-0.0137 * * * \\
(0.0010)\end{array}$ & $\begin{array}{c}-0.0135 * * * \\
(0.0011)\end{array}$ \\
\hline Number of Drugs & $\begin{array}{c}0.0050 \\
(0.0030) \\
\end{array}$ & $\begin{array}{c}0.0040 \\
(0.0029) \\
\end{array}$ & $\begin{array}{l}-0.0024 \\
(0.0024) \\
\end{array}$ & $\begin{array}{c}0.0004 \\
(0.0027) \\
\end{array}$ & $\begin{array}{c}0.0027 \\
(0.0030) \\
\end{array}$ & $\begin{array}{c}0.0028 \\
(0.0033)\end{array}$ \\
\hline Drug Indicators & Yes*** & Yes*** & Yes*** & Yes*** & Yes*** & Yes*** \\
\hline Month Indicators & Yes*** & Yes*** & Yes*** & Yes*** & Yes*** & Yes*** \\
\hline Year Indicators & Yes*** & Yes*** & Yes*** & Yes*** & Yes*** & Yes*** \\
\hline R-Squared & 0.988 & 0.987 & 0.994 & 0.996 & 0.997 & 0.997 \\
\hline Observations & 2728 & 2728 & 1451 & 1163 & 1002 & 886 \\
\hline
\end{tabular}

Notes: Standard errors are corrected for first-order autocorrelation and panel-specific heteroscedasticity, and are reported in parentheses. Elasticity estimates, evaluated at the sample mean, are reported in brackets underneath the relevant promotion measure, where applicable. Advertised drugs denote prescription drugs which have ever undertaken direct-to-consumer advertising at any point over the sample period (1994-2005). Asterisks denote statistical significance as follows: *** p-value $\leq 0.01,{ }^{* *} 0.01<\mathrm{p}$-value $\leq 0.05$, $0.05<$ p-value $\leq 0.10$. 
Table 5

Prescription Drug Price

Advertised Drugs

\begin{tabular}{|c|c|c|c|c|c|c|}
\hline Dependent Variable & \multicolumn{6}{|c|}{ Ln Prescription Drug Price } \\
\hline Model & 1 & 2 & 3 & 4 & 5 & 6 \\
\hline Sample & All & All & $1994-2002$ & $1997-2002$ & $\begin{array}{c}1997 \text { - } 2002 \\
\text { Periods } \\
\text { Under Patent }\end{array}$ & $\begin{array}{c}1997-2002 \\
\text { Balanced Panel } \\
\text { Periods } \\
\text { Under Patent }\end{array}$ \\
\hline $\begin{array}{l}\text { Own Total Broadcast } \\
\text { Advertising Stock }\end{array}$ & $\begin{array}{l}0.0031^{* *} \\
(0.0012)\end{array}$ & $\begin{array}{c}0.0032 * * * \\
(0.0012)\end{array}$ & $\begin{array}{c}0.0118 * * * \\
(0.0032)\end{array}$ & $\begin{array}{c}0.0078 * * * \\
(0.0027)\end{array}$ & $\begin{array}{c}0.0080 * * * \\
(0.0031) \\
\end{array}$ & $\begin{array}{c}0.0169 * * * \\
(0.0049)\end{array}$ \\
\hline $\begin{array}{l}\text { Own Total Broadcast Adv. } \\
\text { Stock - Square }\end{array}$ & $\begin{array}{l}-0.00002 \\
(0.00002)\end{array}$ & $\begin{array}{l}-0.00001 \\
(0.00002)\end{array}$ & $\begin{array}{c}-0.00018^{* * * *} \\
(0.00007)\end{array}$ & $\begin{array}{l}-0.00003 \\
(0.00005)\end{array}$ & $\begin{array}{l}-0.00002 \\
(0.00006)\end{array}$ & $\begin{array}{c}-0.0003 * * \\
(0.0001)\end{array}$ \\
\hline & {$[\varepsilon=0.018]$} & {$[\varepsilon=0.019]$} & {$[\varepsilon=0.042]$} & {$[\varepsilon=0.036]$} & {$[\varepsilon=0.037]$} & {$[\varepsilon=0.049]$} \\
\hline $\begin{array}{l}\text { Own Total Non-Broadcast } \\
\text { Adv. Stock }\end{array}$ & $\begin{array}{l}-0.0019 \\
(0.0018)\end{array}$ & $\begin{array}{l}-0.0017 \\
(0.0018)\end{array}$ & $\begin{array}{c}0.0014 \\
(0.0041)\end{array}$ & $\begin{array}{l}0.0087^{*} \\
(0.0045)\end{array}$ & $\begin{array}{l}0.0077^{*} \\
(0.0046)\end{array}$ & $\begin{array}{c}0.0020 \\
(0.0081)\end{array}$ \\
\hline $\begin{array}{l}\text { Own Total Non-Broadcast } \\
\text { Adv. Stock - Square }\end{array}$ & $\begin{array}{c}0.00002 \\
(0.00003)\end{array}$ & $\begin{array}{l}0.000005 \\
(0.00003)\end{array}$ & $\begin{array}{l}-0.00004 \\
(0.00007)\end{array}$ & $\begin{array}{l}-0.0002 * * * \\
(0.00007)\end{array}$ & $\begin{array}{l}-0.0002 * * * \\
(0.00008)\end{array}$ & $\begin{array}{c}0.0001 \\
(0.00026)\end{array}$ \\
\hline & & & & {$[\varepsilon=0.024]$} & {$[\varepsilon=0.023]$} & \\
\hline $\begin{array}{l}\text { Cross Total Advertising } \\
\text { Stock }\end{array}$ & $\begin{array}{l}-0.0011 \\
(0.0010)\end{array}$ & $\begin{array}{l}-0.0011 \\
(0.0010)\end{array}$ & $\begin{array}{l}-0.0010 \\
(0.0016)\end{array}$ & $\begin{array}{l}-0.0006 \\
(0.0016)\end{array}$ & $\begin{array}{l}-0.0007 \\
(0.0019)\end{array}$ & $\begin{array}{l}-0.0001 \\
(0.0019)\end{array}$ \\
\hline $\begin{array}{l}\text { Cross Total Adv. Stock - } \\
\text { Square }\end{array}$ & $\begin{array}{c}0.000004 \\
(0.000004)\end{array}$ & $\begin{array}{c}0.000004 \\
(0.000003)\end{array}$ & $\begin{array}{l}0.000005 \\
(0.00001)\end{array}$ & $\begin{array}{l}0.000001 \\
(0.00001)\end{array}$ & $\begin{array}{l}0.000001 \\
(0.00001)\end{array}$ & $\begin{array}{r}-0.000002 \\
(0.00001) \\
\end{array}$ \\
\hline Sampling & $\begin{array}{l}-0.0001 \\
(0.0004)\end{array}$ & $\begin{array}{l}-0.0002 \\
(0.0005)\end{array}$ & $\begin{array}{c}0.0010 \\
(0.0007)\end{array}$ & $\begin{array}{l}0.00004 \\
(0.0007)\end{array}$ & $\begin{array}{l}-0.00002 \\
(0.0007)\end{array}$ & $\begin{array}{c}0.0003 \\
(0.0008)\end{array}$ \\
\hline Sampling - Square & $\begin{array}{c}0.000001 \\
(0.000002)\end{array}$ & $\begin{array}{c}0.000001 \\
(0.000002)\end{array}$ & $\begin{array}{l}-0.000001 \\
(0.000003)\end{array}$ & $\begin{array}{c}0.00001 \\
(0.000004)\end{array}$ & $\begin{array}{l}0.00001^{*} \\
(0.000004)\end{array}$ & $\begin{array}{l}0.000002 \\
(0.00001)\end{array}$ \\
\hline Detailing & - & $\begin{array}{c}0.0002 \\
(0.0006)\end{array}$ & - & - & - & - \\
\hline Detailing - Square & - & $\begin{array}{c}0.0000 \\
(0.0000)\end{array}$ & - & - & - & - \\
\hline $\begin{array}{l}\text { Time to Patent Expiration } \\
\text { (PE) }\end{array}$ & $\begin{array}{c}0.0826 * * * \\
(0.0128)\end{array}$ & $\begin{array}{c}0.0716^{* * *} \\
(0.0178)\end{array}$ & $\begin{array}{c}0.2722 * * * \\
(0.0266)\end{array}$ & $\begin{array}{c}0.1127 * * * \\
(0.0126)\end{array}$ & $\begin{array}{c}-0.1295 * * * \\
(0.0326)\end{array}$ & $\begin{array}{c}-0.0830 * * * \\
(0.0226)\end{array}$ \\
\hline Time to PE Squared & $\begin{array}{c}0.0008 \\
(0.0006)\end{array}$ & $\begin{array}{c}0.0007 \\
(0.0006)\end{array}$ & $\begin{array}{c}0.0031 * * * \\
(0.0010)\end{array}$ & $\begin{array}{c}0.0035^{* * *} \\
(0.0009)\end{array}$ & $\begin{array}{c}0.0052 * * * \\
(0.0013)\end{array}$ & $\begin{array}{c}0.0066^{* * *} \\
(0.0013)\end{array}$ \\
\hline Number of Drugs & $\begin{array}{l}-0.0036 \\
(0.0020) \\
\end{array}$ & $\begin{array}{l}-0.0036^{*} \\
(0.0020)\end{array}$ & $\begin{array}{c}0.0061 * * * \\
(0.0019)\end{array}$ & $\begin{array}{c}0.0019 \\
(0.0020)\end{array}$ & $\begin{array}{c}0.0019 \\
(0.0024)\end{array}$ & $\begin{array}{c}0.0025 \\
(0.0026)\end{array}$ \\
\hline Drug Indicators & Yes*** & Yes*** & Yes*** & Yes*** & Yes*** & Yes*** \\
\hline Month Indicators & Yes*** & Yes*** & Yes*** & Yes*** & Yes*** & Yes*** \\
\hline Year Indicators & Yes*** & Yes*** & Yes*** & Yes*** & Yes*** & Yes*** \\
\hline R-Squared & 0.937 & 0.937 & 0.937 & 0.963 & 0.963 & 0.961 \\
\hline Observations & 2729 & 2729 & 1451 & 1163 & 1002 & 886 \\
\hline
\end{tabular}

Notes: Standard errors are corrected for first-order autocorrelation and panel-specific heteroscedasticity, and are reported in parentheses. Elasticity estimates, evaluated at the sample mean, are reported in brackets underneath the relevant promotion measure, where applicable. Advertised drugs denote prescription drugs which have ever undertaken direct-to-consumer advertising at any point over the sample period (1994-2005). Asterisks denote statistical significance as follows: $* * * p$-value $\leq 0.01, * * 0.01<p$-value $\leq 0.05$, $0.05<$ p-value $\leq 0.10$. 
Table 6

Prescription Drug Sales

Price Elasticity for Advertised Drugs

Stratified Periods

\begin{tabular}{|c|c|c|c|c|}
\hline Dependent Variable & \multicolumn{4}{|c|}{ Ln Prescription Drug Sales } \\
\hline Model & 1 & 2 & 3 & 4 \\
\hline Sample & \multicolumn{2}{|c|}{ Periods under Patent } & \multicolumn{2}{|c|}{$\begin{array}{c}\text { Periods under Patent } \\
\text { Balanced Panel }\end{array}$} \\
\hline Time Period & $1997-1999$ & $2000-2002$ & $2000-2002$ & $2000-2002$ \\
\hline Ln Price & $\begin{array}{c}-0.8232 * * * \\
(0.0434)\end{array}$ & $\begin{array}{c}-0.5321 * * * \\
(0.0736)\end{array}$ & $\begin{array}{c}-0.5020 * * * \\
(0.0744)\end{array}$ & $\begin{array}{c}-0.5027 * * * \\
(0.0740)\end{array}$ \\
\hline $\begin{array}{l}\text { Own Total Broadcast } \\
\text { Advertising Stock }\end{array}$ & $\begin{array}{c}0.0347 * * * \\
(0.0110)\end{array}$ & $\begin{array}{c}0.0074 * * \\
(0.0030)\end{array}$ & $\begin{array}{c}0.0181 * * * \\
(0.0064)\end{array}$ & $\begin{array}{c}0.0195 * * * \\
(0.0065)\end{array}$ \\
\hline $\begin{array}{l}\text { Own Total Broadcast Adv. } \\
\text { Stock - Square }\end{array}$ & $\begin{array}{l}-0.0009^{*} \\
(0.0004)\end{array}$ & $\begin{array}{c}-0.0001 * * \\
(0.0001)\end{array}$ & $\begin{array}{c}-0.0005^{*} * * \\
(0.0002)\end{array}$ & $\begin{array}{c}-0.0005 * * * \\
(0.0002)\end{array}$ \\
\hline & {$[\varepsilon=0.052]$} & {$[\varepsilon=0.038]$} & {$[\varepsilon=0.068]$} & {$[\varepsilon=0.073]$} \\
\hline $\begin{array}{l}\text { Own Total Non-Broadcast } \\
\text { Adv. Stock }\end{array}$ & $\begin{array}{c}-0.0421 * * * \\
(0.0148)\end{array}$ & $\begin{array}{l}0.0094^{*} \\
(0.0052) \\
\end{array}$ & $\begin{array}{l}-0.0012 \\
(0.0134)\end{array}$ & $\begin{array}{l}-0.0003 \\
(0.0131)\end{array}$ \\
\hline $\begin{array}{l}\text { Own Total Non-Broadcast } \\
\text { Adv. Stock - Square }\end{array}$ & $\begin{array}{l}0.0010 * \\
(0.0006)\end{array}$ & $\begin{array}{l}-0.0001 \\
(0.0001)\end{array}$ & $\begin{array}{c}0.0006 \\
(0.0004) \\
\end{array}$ & $\begin{array}{c}0.0005 \\
(0.0004) \\
\end{array}$ \\
\hline & {$[\varepsilon=-0.077]$} & {$[\varepsilon=0.041]$} & {$[\varepsilon=0.007]$} & {$[\varepsilon=0.009]$} \\
\hline $\begin{array}{l}\text { Cross Total Advertising } \\
\text { Stock }\end{array}$ & $\begin{array}{c}0.0001 \\
(0.0049) \\
\end{array}$ & $\begin{array}{c}0.0005 \\
(0.0013) \\
\end{array}$ & $\begin{array}{l}-0.0007 \\
(0.0016) \\
\end{array}$ & $\begin{array}{l}-0.0007 \\
(0.0016) \\
\end{array}$ \\
\hline $\begin{array}{l}\text { Cross Total Adv. Stock - } \\
\text { Square }\end{array}$ & $\begin{array}{l}0.00002 \\
(0.0001)\end{array}$ & $\begin{array}{l}-0.000003 \\
(0.00001) \\
\end{array}$ & $\begin{array}{l}0.000004 \\
(0.00001) \\
\end{array}$ & $\begin{array}{c}0.00001 \\
(0.00001) \\
\end{array}$ \\
\hline Sampling & $\begin{array}{c}0.0017 \\
(0.0030) \\
\end{array}$ & $\begin{array}{l}0.0032 * \\
(0.0017) \\
\end{array}$ & $\begin{array}{l}0.0034^{*} \\
(0.0020) \\
\end{array}$ & $\begin{array}{l}0.0035^{*} \\
(0.0020) \\
\end{array}$ \\
\hline Sampling - Square & $\begin{array}{c}0.0000003 \\
(0.00003)\end{array}$ & $\begin{array}{l}-0.00001 \\
(0.00001)\end{array}$ & $\begin{array}{l}-0.00001 \\
(0.00001)\end{array}$ & $\begin{array}{l}-0.00001 \\
(0.00001)\end{array}$ \\
\hline & {$[\varepsilon=0.032]$} & {$[\varepsilon=0.032]$} & {$[\varepsilon=0.056]$} & {$[\varepsilon=0.057]$} \\
\hline $\begin{array}{l}\text { Time to Patent Expiration } \\
\text { (PE) }\end{array}$ & $\begin{array}{c}0.6681 * * * \\
(0.0285)\end{array}$ & $\begin{array}{c}0.3050 * * * \\
(0.0634)\end{array}$ & $\begin{array}{l}-0.0376 \\
(0.1174) \\
\end{array}$ & $\begin{array}{c}0.2357 * * * \\
(0.0781) \\
\end{array}$ \\
\hline Time to PE Squared & $\begin{array}{c}-0.0099 * * * \\
(0.0013)\end{array}$ & $\begin{array}{c}-0.0177 * * * \\
(0.0025)\end{array}$ & $\begin{array}{c}-0.0101 * * \\
(0.0042) \\
\end{array}$ & $\begin{array}{c}-0.0108 * * \\
(0.0043) \\
\end{array}$ \\
\hline Number of Drugs & $\begin{array}{c}0.0020 \\
(0.0043) \\
\end{array}$ & $\begin{array}{c}0.0007 \\
(0.0036) \\
\end{array}$ & $\begin{array}{c}0.0011 \\
(0.0044) \\
\end{array}$ & $\begin{array}{c}0.0022 \\
(0.0046) \\
\end{array}$ \\
\hline Drug Indicators & Yes*** & Yes*** & Yes*** & Yes*** \\
\hline Month Indicators & Yes*** & Yes*** & Yes*** & Yes*** \\
\hline Year Indicators & Yes*** & Yes*** & Yes*** & Yes*** \\
\hline Drugclass * Year Indicators & No & No & No & Yes \\
\hline R-squared & 0.998 & 0.999 & 0.997 & 0.997 \\
\hline Observations & 469 & 529 & 419 & 419 \\
\hline
\end{tabular}

Notes: Standard errors are corrected for first-order autocorrelation and panel-specific heteroscedasticity, and are reported in parentheses. Elasticity estimates, evaluated at the sample mean, are reported in brackets underneath the relevant promotion measure, where applicable. Advertised drugs denote prescription drugs which have ever undertaken direct-to-consumer advertising at any point over the sample period (1994-2005). Asterisks denote statistical significance as follows: $* * *$ p-value $\leq 0.01, * * 0.01<\mathrm{p}$-value $\leq 0.05,0.05<\mathrm{p}$-value $\leq 0.10$. 
Table 7

Simulations

\begin{tabular}{|c|c|c|c|}
\hline Variable & $\begin{array}{l}\text { Drug Price } \\
\quad \text { (in \$) }\end{array}$ & $\begin{array}{c}\text { Drug Sales } \\
\text { (in millions of extended units) }\end{array}$ & $\begin{array}{l}\text { Total Expenditures } \\
\text { (in millions } \$)^{1}\end{array}$ \\
\hline Actual 2005 & 41.02 & 21.41 & 93.42 \\
\hline \multicolumn{4}{|c|}{$\begin{array}{c}\text { Simulation: } \\
\text { Complete Ban of Broadcast DTCA } \\
(\text { Total Stock of Broadcast DTCA }=0)\end{array}$} \\
\hline Predicted 2005 & 37.11 & 16.99 & 65.24 \\
\hline$\%$ Change & $-9.5 \%$ & $-20.6 \%$ & $-30.1 \%$ \\
\hline \multicolumn{4}{|c|}{$\begin{array}{l}\text { Simulation: } \\
\text { 50\% Reduction in Total Stock of Broadcast DTCA }\end{array}$} \\
\hline Predicted 2005 & 39.20 & 19.41 & 80.56 \\
\hline \% Change & $-4.4 \%$ & $-9.3 \%$ & $-13.7 \%$ \\
\hline
\end{tabular}

Note: Due to skewed distributions of drug price and drug sales, the mean of total expenditures is not equal to the product of the mean drug price and mean drug sales. Predicted changes are based on the average parameter estimates from specifications 5 and 6 in Table 4 (for drug sales) and specifications 5 and 6 in Table 5 (for drug price). 